\title{
TOLERANCE VALUES AND EFFECTS OF SELECTED ENVIRONMENTAL DETERMINANTS ON CADDISFLY (TRICHOPTERA) DISTRIBUTION IN NORTHWEST AND NORTH CENTRAL WASHINGTON, USA
}

\author{
Dean W. Blinn ${ }^{1}$ and David E. Ruiter ${ }^{2}$
}

\begin{abstract}
Aвstract.-Caddisflies were collected at 181 wall seep, stream, river, and lake habitats in 7 counties in northwest and north central Washington over a 6-year period. From 17,405 specimens, we identified 164 adult caddisfly species within 62 genera and 16 families. Twenty taxa were new state records, bringing the number of species currently reported from Washington to 230. Species assemblages were compared to altitude, physicochemical factors, aquatic habitats, and land use (urban, agriculture, and forest) on the west and east sides of the North Cascade Range. Species richness showed significant positive correlations to altitude and $\mathrm{pH}$ and showed significant negative correlations to total phosphorus, total nitrogen, and specific conductivity, as well as especially to channel embeddedness. A multilevel hierarchical clustering model separated wall seeps, streams, and rivers into geographic and land-use regions based on adult caddisfly assemblages. We used a multimetric index (caddisfly tolerance index [CTI]) to determine environmental tolerance levels for adult caddisfly species. The index performed well in distinguishing among the effects of total phosphorus, total nitrogen, specific conductance, and channel embeddedness on the distribution of caddisfly species. These CTI values provide baseline information for monitoring changes in ecosystem health in drainages throughout Washington landscapes.
\end{abstract}

RESUMEN.-Se colectaron frigáneas en 181 hábitats que incluyen filtraciones en paredes, arroyos, ríos y lagos, en siete condados ubicados en el noroeste y la parte norte-central de Washington, en un período de seis años. Identificamos 164 especies adultas de frigáneas de 62 géneros y 16 familias de 17,405 especímenes. Se registraron veinte nuevos taxones en el estado, 230 especies ya reportadas en Washington. Se compararon distintos ensambles de especies en relación con la altitud, los factores fisicoquímicos, los hábitats acuáticos y la explotación del suelo (urbano, agrícola y bosque) en el lado oeste y este de North Cascade Range. La riqueza de especies mostró correlaciones positivas significativas en relación con la altitud y el $p H$, y correlaciones negativas significativas con el fósforo total, el nitrógeno, la conductividad específica y, en especial, con la superposición de los cauces de agua. Un modelo de agrupamiento jerárquico multinivel separó las filtraciones en paredes, los arroyos y los ríos, en regiones geográficas y de explotación del suelo, según los grupos de adultos de frigáneas. Utilizamos un índice multimétrico (Índice de tolerancia de frigáneas [CTI, por sus siglas en inglés]) para determinar los niveles de tolerancia ambiental para adultos de las especies de frigáneas. El índice funcionó correctamente para distinguir entre el efecto del fósforo total, el nitrógeno total, la conductancia específica y la superposición de los cauces de agua en la distribución de las especies de frigáneas. Estos valores del CTI proporcionan información de referencia para monitorear los cambios de estado del ecosistema en los desagües de los paisajes de Washington.

Few studies have been published on the distribution of caddisflies in Washington, even though the state includes parts of 13 terrestrial (Ricketts et al. 1999) and 3 freshwater ecoregions (Abell et al. 2000). The terrestrial ecoregions range from central Pacific coastal forests to Palouse grasslands. In the USA, only California is as diverse in its terrestrial ecoregions as Washington (Ricketts et al. 1999). We propose that the high diversity of ecoregions in Washington should yield equally high diversity in caddisfly assemblages.

One of the earliest published collections of caddisflies in Washington was by Davis (1948), who reported 102 species from 17 counties throughout the state. Six of these counties are included in this study. In addition, Ruiter et al. (2005) reported 117 species from Mt. Rainer National Park, while Zack et al. (2006) collected 40 caddisfly species in a springstream system in the semiarid southeastern region at the Hanford Reach National Monument. Betts and Wisseman (1995) reported on the geographic range and habitat characteristics of Cryptochia neosa in the Blue Mountains of Washington.

Distributions of caddisflies have been published for nearby regions. Anderson (1976)

1Department of Biological Sciences, Northern Arizona University, Flagstaff, AZ 86011. E-mail: deandiacad@comcast.net

2235 SW Central Avenue, Grants Pass, OR 97526. 
reported 282 caddisfly species in Oregon, while Cannings (2007) published an updated list of 275 species in British Columbia, Canada. In addition, there have been 156 species of caddisflies reported in Idaho (J. Pappani, Idaho Department of Environmental Quality, personal communication; Newell and Minshall 1977).

Many of the aquatic habitats (urban, agricultural, forest) included in this study are considered vulnerable and endangered, with a high to medium likelihood of future threats (Abell et al. 2000). The threats to these freshwater ecoregions include increased agriculture and urbanization, loss of floodplain and riparian habitats from forest clearing, and increased turbidity and channel embeddedness in streams. These conditions may increase the potential of losing existing fauna, as well as potentially undescribed endemic species.

Caddisflies play important roles in food webs (Couceiro et al. 2007) and ecological processes such as leaf breakdown (Vannote et al. 1980). Also, Céréghino et al. (2003) reported that caddisflies were good predictors of environmental conditions along stream orders because various species occupy the full spectrum of altitudinal gradients. In addition, Houghton (2006) determined that adult caddisflies were an important group for biomonitoring farmland streams in Minnesota because of their high species richness, ecological diversity, and abundance in all types of freshwater ecosystems. Finally, Cuffney et al. (2011) found invertebrate responses to land-cover disturbances more sensitive than algal responses in urban environments.

Paulsen et al. (2008) examined the ecological conditions of wadeable, perennial streams and small rivers in 3 major ecoregions in the United States, which included the western USA. Nationally, $42 \%$ of the stream length was in poor condition. The most widespread stressors observed were nitrogen, phosphorus, riparian disturbance, and streambed sediments.

We provide an updated list of adult caddisfly species for Washington and discuss the role of total nitrogen (TN), total phosphorus (TP), specific conductance, channel embeddedness, maximum water temperature, canopy cover, altitude, land use, and habitat type on the distribution of these species.

Ecologists have recommended indices based on the most robust and finest taxonomic resolution over family or generic resolution for the bioassessment of habitats and landscapes (Hawkins and Norris 2000, Whittier and Van Sickle 2010). Also, Barbour et al. (1995) recommended a multimetric approach for measuring biological conditions.

We developed tolerance values for adult caddisfly species based on nutrients (TN, TP), specific conductance, and channel embeddedness. These tolerance values provide a baseline for monitoring changes in ecosystem health for aquatic ecosystems in Washington State. To date, no tolerance rankings have been developed for adult caddisflies in the varied landscapes of Washington.

\section{Study Area}

The study area encompasses about 48,000 $\mathrm{km}^{2}$ and 7 counties in northwest and central Washington (Fig. 1A-1C). The region includes the North Pacific Coastal and Columbia Glaciated freshwater ecoregions with a variety of temperate coastal seeps, streams, rivers, and lakes (Abell et al. 2000). The North Pacific Coastal Region includes mesic landscapes on the west side of the North Cascade Range and a drier Columbia Glaciated Region east of the Cascade Range.

Landscapes contain a number of urban communities with a combined total of over 250,000 residents (http://quickfacts.census.gov; cited 6 January 2013). Bellingham is the largest urban center, with about 82,000 residents; most other urban centers have $<5000$ residents. Dairy, corn, and berry farming make up a large portion of the agricultural landscapes on the west side of the Cascade Range, whereas dryland crops and rangelands are common on the east side of the Cascade Range (personal observations). The urban and agricultural landscapes are typically $<300 \mathrm{~m}$ in altitude, and most forest landscapes range from 300 to $>2000 \mathrm{~m}$.

Riparian vegetation in urban landscapes includes Acer macrophyllum, Alnus rubra, and Pseudotsuga menziesii, whereas agricultural landscapes include grasses, sedges, and $\mathrm{Al}$ nus rubra. Riparian vegetation along lowland forest sites contains Acer macrophyllum, Alnus rubra, Salix scouleriana, Salix sitchensis, Pseudotsuga menziesii, and Populus balsamifera ssp. trichocarpa, which is replaced by Tsuga heterophylla in upland riparian systems (Pojar and MacKinnon 1994). Riparian 


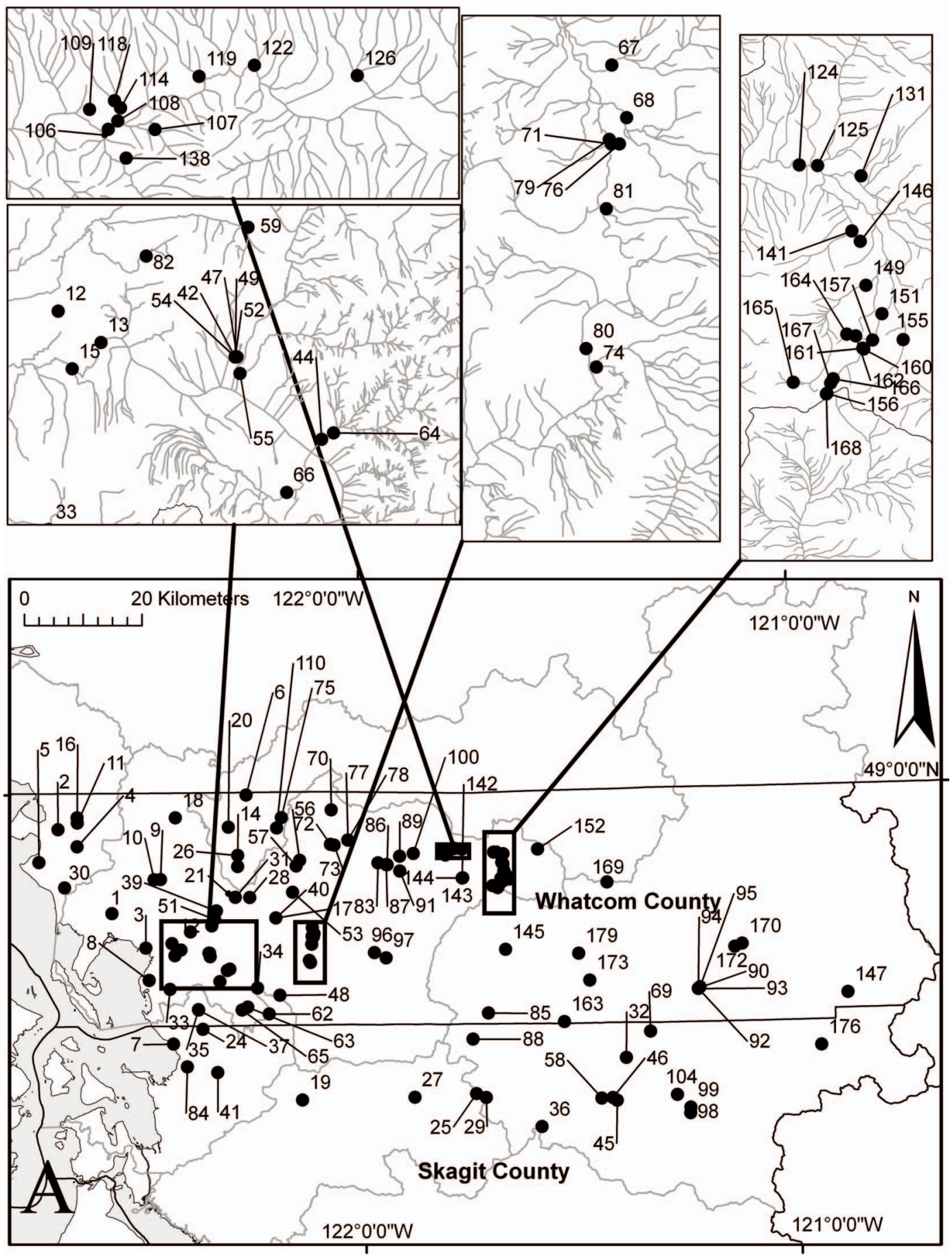

Fig. 1. Location of collection sites in northwest and north central Washington. Site numbers are taken from Appendix 1: 1A, sites in Whatcom and Skagit counties; 1B (facing page), sites in Chelan, King, Kittitas, Skagit, and Snohomish counties; 1C (facing page), sites in Chelan and Okanogan counties. 

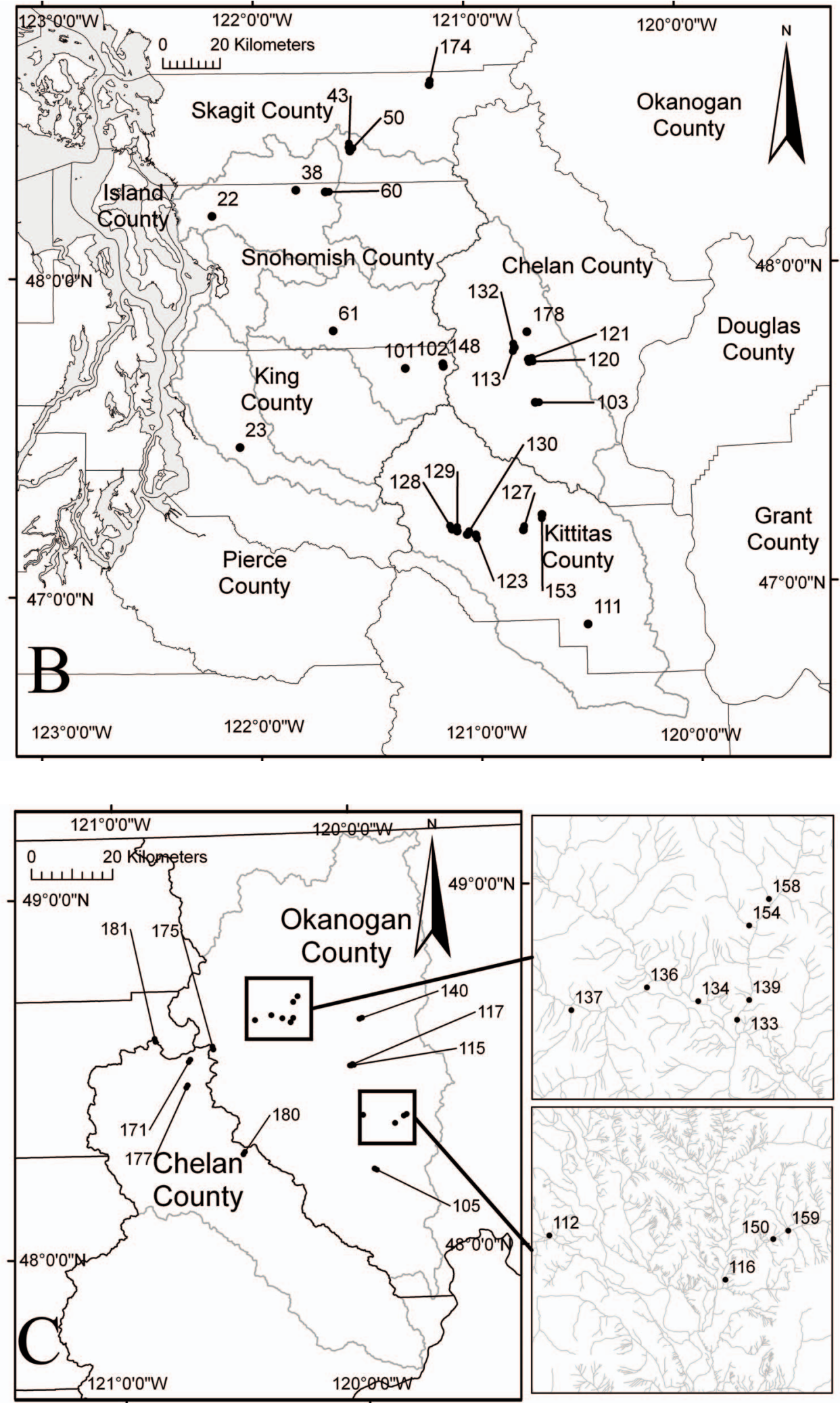
vegetation in drier eastern Washington includes Pseudotsuga menziesii, Pinus ponderosa, and dry grassland vegetation (personal observation).

\section{Methods}

Adult and immature caddisflies were collected from 12 wall seeps (water draining down rock faces), 107 streams, 35 rivers, and 27 lakes and ponds from 2006 through 2011 in northwest and north central Washington (Appendix 1). Adult caddisflies were collected between early April and mid-November by using a 12-cm, 4-W ultraviolet light placed over a 14 $\times 21-\mathrm{cm}$ plastic tray containing $70 \%$ isopropyl alcohol. Two trays were placed at different locations near the site $1 \mathrm{~h}$ before sunset and retrieved after 5-6 h. Species abundance was determined as the percentage of captured adults and averaged for each site over the 6year period. Caddisfly larvae and pupae were handpicked from submerged vegetation, rocks, and woody debris during most visits in order to compare them with adult collections. Seventy percent of the sites were sampled in 2 different years, $16 \%$ were sampled in 3 different years, and $80 \%$ were sampled at least twice during a one-year period. Specimens were identified to the lowest feasible taxon using the available taxonomic literature, and they are deposited in the David E. Ruiter Personal Collection (DERPC) located in Grants Pass, Oregon.

Land use (urban, agriculture, forest) was noted based on observations, and physicochemical information was collected at each site. Air temperatures and maximum water temperatures for every collection were measured with a handheld thermometer on-site when trays were placed and retrieved. Specific conductance of water (at $25^{\circ} \mathrm{C}$ ) was determined with a conductance meter (Radiometer, Copenhagen, Denmark; Model CDM2e) in the laboratory, and $\mathrm{pH}$ was measured with an Oakton pH 6 meter on-site. Channel embeddedness was determined to the nearest $5 \%$ interval at each site following methods of Platts et al. (1983). Suspended sediments were determined according to MacDonald et al. (1991), and canopy cover was determined with a spherical densiometer (Forest Densiometer Model A) to the nearest 5\% interval.

Water collections for TN and TP were immediately placed on dry ice and analyzed within 14 days by the persulfate digestion and flow injection method on an FS3000 Flow Injection Analyzer made by OI Corporation (APHA 2005). The digestion method was an alkaline oxidation (APHA 4500-PJ) using sodium hydroxide and potassium persulfate. Following the digestion, total phosphorus was measured using the ascorbic acid method (APHA 4500-PH), and total nitrogen was measured using the cadmium reduction method on the FS3000 (APHA 4500 NO3-I).

Kendall's tau $(\tau)$ rank correlation coefficients were calculated between species richness and TN, TP, specific conductance, channel embeddedness, altitude, maximum water temperature, $\mathrm{pH}$, suspended solids, and percent canopy. We also used principal components analysis based on singular value decomposition of the centered, scaled data matrix to extract the important relationships among the water quality and caddisfly variables (Jongman et al. 1995, Ben-Hur and Guyon 2003, R Development Core Team 2011). The principal components were used as new variables to identity stable clusters using hierarchical clustering with Euclidean distance and Ward's minimum variance cluster method, following the methods outlined by Ben-Hur and Guyon (2003).

A tolerance index was developed for $\mathrm{TN}$, TP, specific conductance, and channel embeddedness to compare the distribution of adult caddisfly species along each of these environmental gradients. The following equation was developed by Blinn (1993) for specific conductance (SCI) and used by Blinn and Bailey (2001) for diatoms and Blinn and Ruiter (2006) for caddisflies:

$\mathrm{SCI}_{x}=\frac{\sum\left[\log _{10}\left(R A_{\mathrm{i}} \cdot 100\right)\right](\text { Specific Conductance, } \mu \mathrm{S} / \mathrm{cm})}{N_{x}}$,

where $R A=$ relative abundance $(\%)$ of species $x$ at a given stream site and $N=$ number of streams in which species $x$ occurred. The Caddisfly Tolerance Index (CTI) is a summation of the adjusted combined numeric values of TNI, TPI, SCI, and EMBI. Elevated nutrients, salinization of water, and siltation of cobbles are 3 of the most influential stressors for stream biota (Laws 2000, Enger and Smith 2009). We adjusted the CTI numeric scores to a 0-10 scale in order to compare with values 


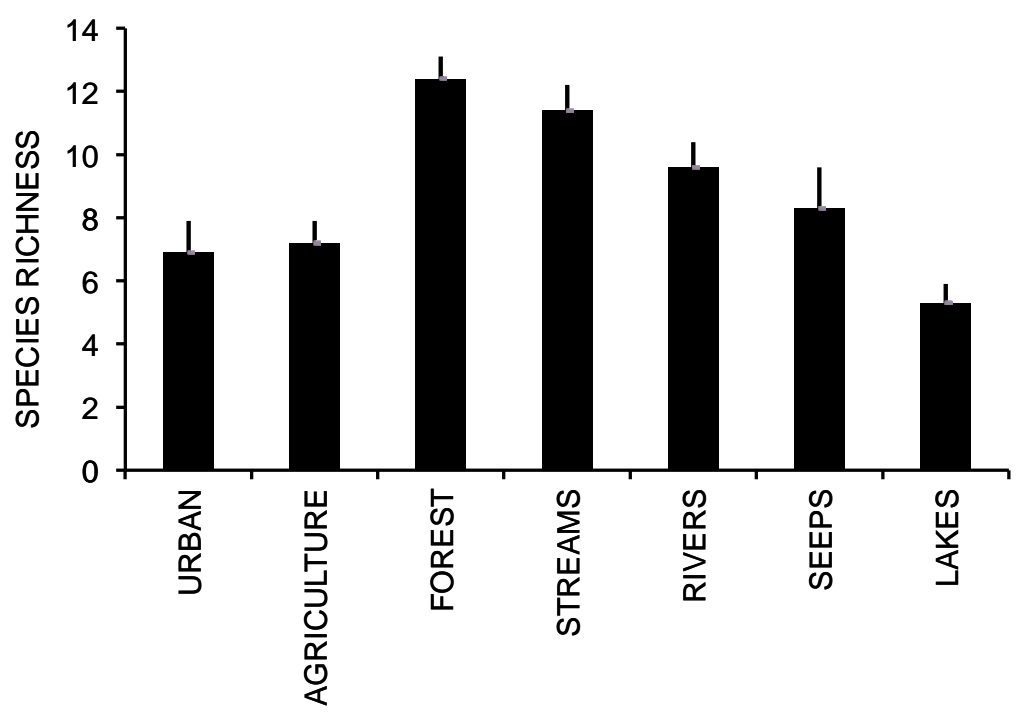

Fig. 2. Mean caddisfly species richness for land use and habitats in northwest and north central Washington.

from the U.S. Environmental Protection Agency (Barbour et al. 1999).

\section{RESULTS}

Caddisfly Distribution and Physicochemical Features

We identified 164 caddisfly species within 62 genera and 16 families from 17,405 specimens, which resulted in 20 new records for the state (Morse 2009; Appendix 2). Ruiter et al. (2005) summarized the literature on the distribution of caddisfly species and reported at least 210 species from Washington. The addition of 20 species in this study resulted in at least 230 caddisfly species recorded for the state.

Forty-six species were collected in wall seeps, 140 in streams and rivers, and 38 in lakes (Appendix 2). All families were represented in stream habitats. Members of Phryganeidae and Rhyacophilidae were common in wall seeps, and Leptoceridae, Limnephilidae, Phryganeidae, and Polycentropodidae were common in lakes. Forest landscapes and streams had the highest mean number of species per site, and urban landscapes and lakes had the lowest mean number of species (Fig. 2). Overall average species richness per site was 9.6 (SE 0.6) on the west side and 9.8 (SE 0.9) on the east side of the North Cascade Range.
One hundred fifty-one taxa were collected on the west side of the North Cascade Range and 71 taxa on the east side (Appendix 2). Hydropsychidae, Hydroptilidae, Lepidostomatidae, Limnephilidae, Philopotamidae, and Rhyacophiladae composed $76 \%$ of the caddisfly assemblages collected on the west side. In contrast, Glossosomatidae, Hydropsychidae, Hydroptilidae, Leptoceridae, Limnephilidae, and Rhyacophilidae made up $79 \%$ of the caddisfly assemblage on the east side. No species in Goeridae, Odontoceridae, or Phryganeidae were collected on the east side of the Cascade Range.

Caddisfly species richness showed significant positive correlations to altitude and $\mathrm{pH}$ and showed significant negative correlations to TN, TP, specific conductivity, and especially channel embeddedness (Table 1). No significant correlations were determined between species richness and suspended solids, maximum water temperature, or canopy cover.

Two limnephilids, Ecclisomyia conspersa and Onocosmoecus unicolor, were the most common species collected from both west and east sides of the Cascade Range (Appendix 2 ). These species were collected in nearly one-third of all the sites examined at altitudes ranging from $4 \mathrm{~m}$ to $>1300 \mathrm{~m}$. Ecclisomyia conspersa was collected in all habitats, whereas Onocosmoecus unicolor was collected only in streams. Hydropsyche oslari (29.1\%), Parapsyche elsis (27.9\%), Polycentropus variegatus 
TABLE 1. Kendall's $\tau$ rank-based correlations between caddisfly species richness and environmental determinants. An asterisk (*) indicates statistical significance.

\begin{tabular}{lcc}
\hline & Kendall's $\tau$ & $P$ value \\
\hline Altitude* & 0.233 & 0.0002 \\
Specific conductivity* & -0.157 & 0.0125 \\
Maximum water temperature & -0.091 & 0.1590 \\
Total phosphorus* & -0.152 & 0.0149 \\
Total nitrogen* & -0.158 & 0.0103 \\
pH* & 0.197 & 0.0027 \\
Suspended solids & -0.041 & 0.5580 \\
\% Canopy cover & -0.033 & 0.6260 \\
Channel embeddedness* & -0.198 & 0.0030 \\
\hline
\end{tabular}

(27.1\%), Rhyacophila vao (26.7\%), and Arctopsyche grandis $(26 \%)$ were the next most common species throughout the study area. These species were collected primarily in streams and wall seeps from west and east sites of the Cascade Range. Limnnephilidae and Rhyacophiladae had the most species, with 40 and 35 species, respectively. Eight species (Sisko sp., Tinodes cascadia, Rhyacophila chilsia, Rhyacophila fenderi, Rhyacophila norcuta, Rhyacophila rotunda, Rhyacophila viquaea, and Rhyacophila visor) were collected only in wall seep habitats on the west side of the Cascade Range (Appendix 2).

Limnephilids, including Chyranda centralis, Ecclisocosmoecus scylla, Ecclisocosmoecus conspersa, Eocosmoecus frontalis, Lenarcus vastus, and Psychoglypha alascensis, and one uenoidid, Neothremma didactyla, were common in high-altitude lakes (>1200 m; Appendix 2). Hydroptilidae (Agraylea multipunctata, Stactobiella delira), Leptoceridae (Mystacides alafimbriata, Oecetis inconspicua, Triaenodes tardus), and Polycentropidae (Polycentropus cinereus, Polycentropus variegatus) were common in lakes at altitudes $<400 \mathrm{~m}$. No members of the Apataniidae, Brachycentridae, Glossosomatidae, Goeridae, Hydropsychidae, Odontoceridae, Philopotamidae, and Psychomyiidae were collected in lakes. Chyranda centralis, Ecclisocosmoecus conspersa, and Neophylax splendens were common in wall seep habitats.

Specific conductance ranged from 0.004 to $26.2 \mathrm{mS} \cdot \mathrm{cm}^{-1}$, TP from 4 to $787 \mu \mathrm{g} \cdot \mathrm{L}^{-1}$, TN from 0.8 to $5615 \mu \mathrm{g} \cdot \mathrm{L}^{-1}$, and channel embeddedness from $5 \%$ to $99 \%$ throughout the study area (Appendix 1, Table 1). Average TN concentrations were 7 times higher in agricultural landscapes on the west side of the Cascade Range compared to the east side (Table 1).
Other relationships between environmental parameters on the west and east sides of the Cascade Range can be found in Table 2.

Hierarchical clustering produced 5 stable cluster groups using the first 5 principal components as clustering variables (Fig. 3). These cluster groups appeared to match natural groups formed by geographic location and land-use type. A simple chi-square contingency table showed a significant association between the 5 "blind" hierarchical cluster groups and the following location/land-use groups (Crawley 2007). Clusters A, B ${ }^{1}$, and $\mathrm{B}^{2}$ contained wall seeps and streams primarily on the west side of the North Cascade mountain range, whereas cluster $\mathrm{C}$ contained both streams and rivers mostly on the west side, and D included streams and rivers mostly on the east side of the Cascades.

Cluster A included high-altitude habitats $(\geq 350 \mathrm{~m})$ in the Mount Baker region on the west side of the Cascade Range. Average concentrations for TP and $\mathrm{TN}$ were $7 \mu \mathrm{g} \cdot \mathrm{L}^{-1}(\mathrm{SE}$ 1.1) and $81.5 \mu \mathrm{g} \cdot \mathrm{L}^{-1}(\mathrm{SE} 15)$, respectively. Varden and Jack creeks, also high-altitude sites, were the only sites included in Cluster A from the east side of the North Cascades. Cluster $\mathrm{B}^{1}$ included shallow streams in regions with low altitudes $(<35 \mathrm{~m})$ and heavy agriculture including dairy, berry, and corn farms with high average TP $\left(48.3 \mu \mathrm{g} \cdot \mathrm{L}^{-1}, \mathrm{SE} 11.1\right)$ and TN $\left(2509 \mu \mathrm{g} \cdot \mathrm{L}^{-1}\right.$, SE 651$)$ concentrations.

$\mathrm{B}^{2}$ included streams at altitudes $\leq 165 \mathrm{~m}$ with limited agriculture (ranching and horses) and small urban areas with TP and TN concentrations of $9.8 \mu \mathrm{g} \cdot \mathrm{L}^{-1}(\mathrm{SE} 1.3)$ and $488 \mu \mathrm{g} \cdot$ $\mathrm{L}^{-1}$ (SE 77), respectively. Cluster C included streams/rivers at altitudes $<400 \mathrm{~m}$ primarily on the west side of the Cascades with TP and TN concentrations of $18 \mu \mathrm{g} \cdot \mathrm{L}^{-1}$ (SE 2.9) and $137 \mu \mathrm{g} \cdot \mathrm{L}^{-1}$ (SE 27), respectively. And Cluster D included streams/rivers at altitudes $>400 \mathrm{~m}$ primarily on the east side of the Cascades with similar low concentrations of TP $\left(15.8 \mu \mathrm{g} \cdot \mathrm{L}^{-1}\right.$, SE 3.6) and TN $\left(119 \mu \mathrm{g} \cdot \mathrm{L}^{-1}\right.$, SE 26).

Caddisfly assemblages in Cluster A with limited landscape disturbance included Chyranda centralis, Dolophilodes pallidipes, Ecclisocosmoecus scylla, Ecclisocosmoecus conspersa, Homophylax andax, Oligophiloides sierra, Rhyacophila vaccua, Rhyacophila vaefes, and Rhyacophila vocala. Common assemblages associated with heavy agricultural land use in Cluster $\mathrm{B}^{1}$ included Agraylea multipunctata, 


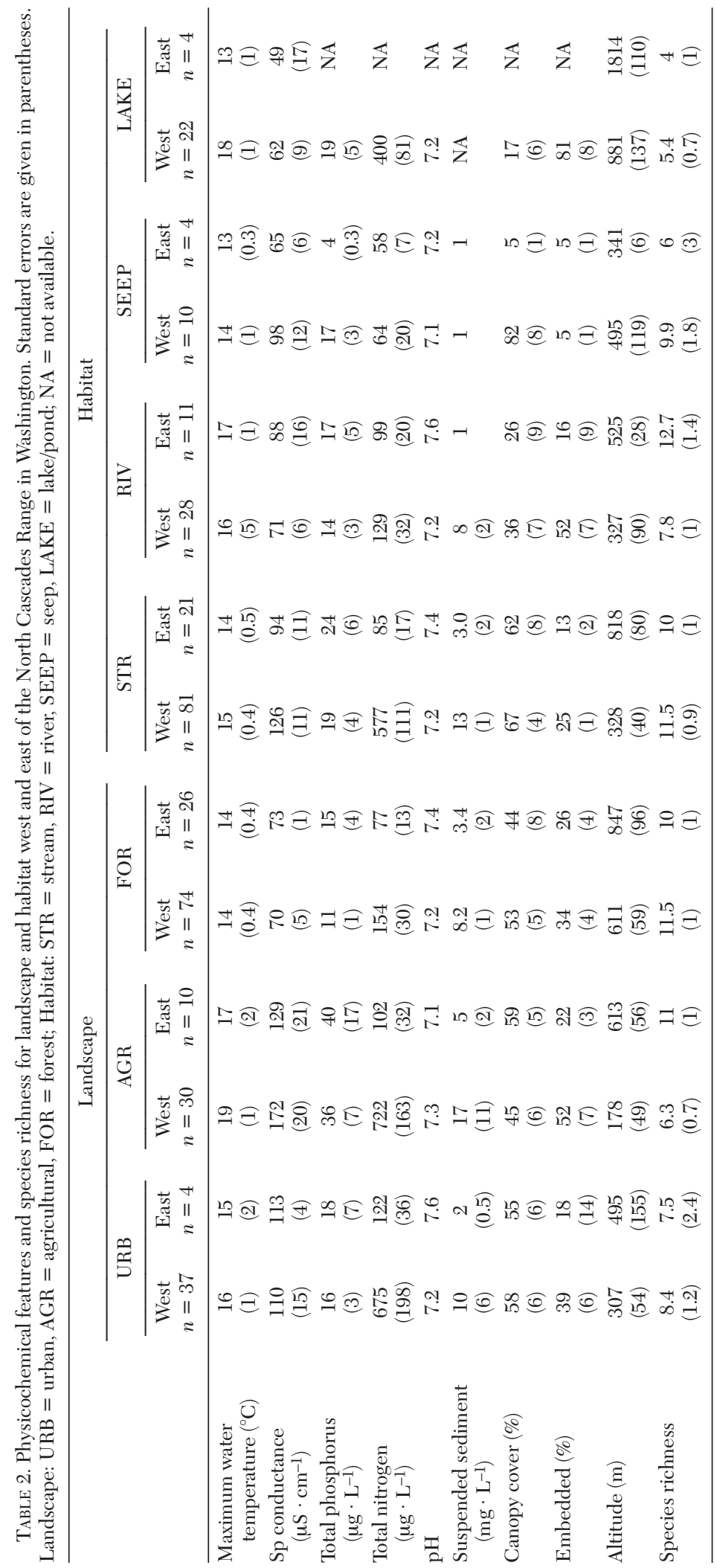




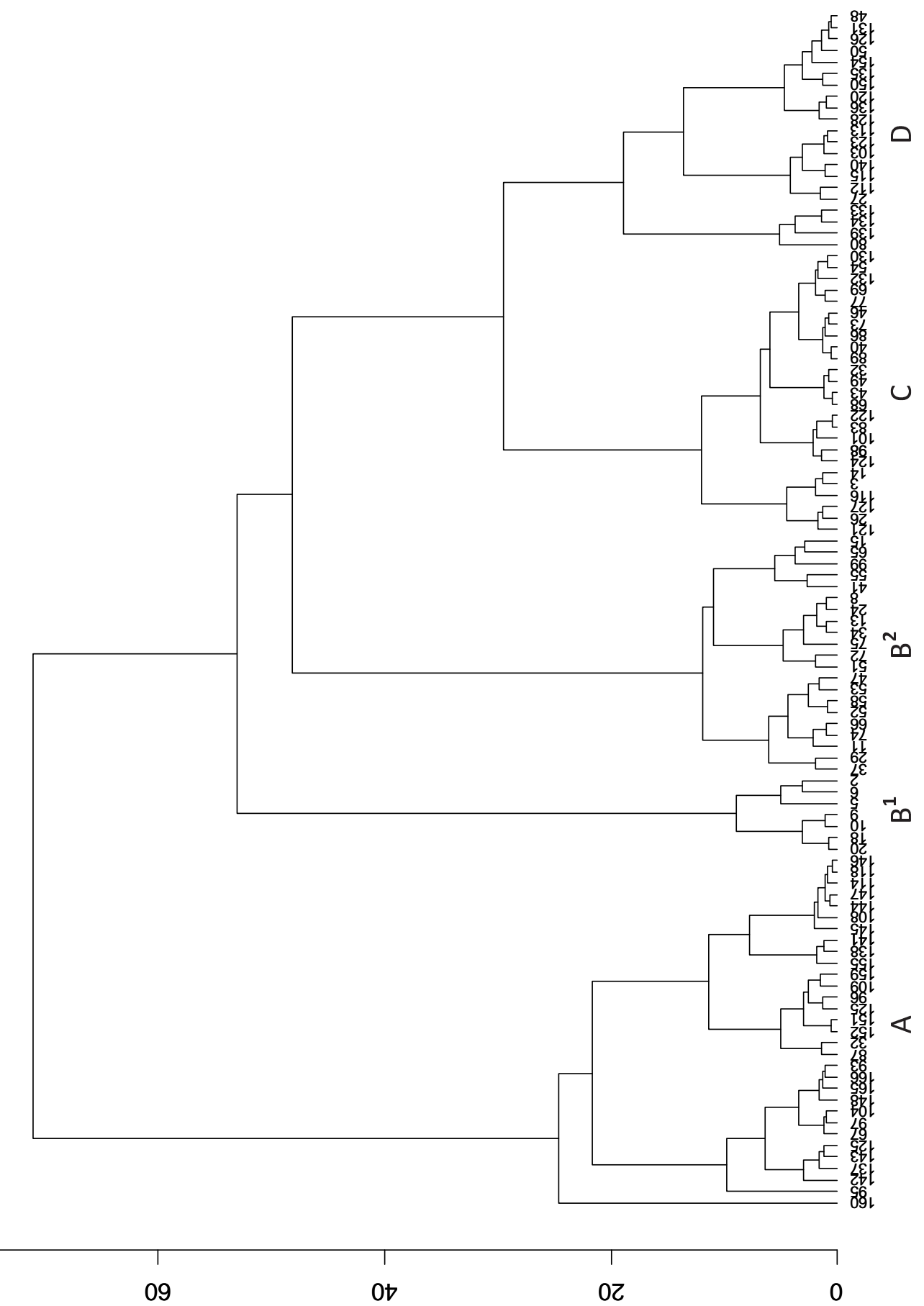

Fig. 3. Multilevel hierachial clustering using 6 environmental factors for seeps, streams, and rivers in northwest and north central Washington. Site numbers in Appendix 1 are listed on the $\mathrm{x}$-axis. A = seeps and streams at altitudes $\geq 350 \mathrm{~m}$, primarily in the Mount Baker area (31 sites); $\mathrm{B}^{1}=$ streams at altitudes $\leq 35 \mathrm{~m}$ in landscapes with heavy agriculture (dairy, berry, and corn) on the west side of the Cascades ( 7 sites); $\mathrm{B}^{2}=$ streams at altitudes $\leq 165 \mathrm{~m}$ in moderate agricultural (alfalfa and ranching) and urban landscapes on the west side of the Cascades (21 sites); $\mathrm{C}=$ streams and rivers at altitudes $<400 \mathrm{~m}$, primarily on the west side of the Cascades (25 sites); D = streams and rivers at altitudes $>400 \mathrm{~m}$, primarily on the east side of the Cascades (21 sites). 
TABLE 3. Caddisfly tolerance index (CTI) for species collected in Washington. Lower tolerance values indicate that species are sensitive to the environmental parameter: $\mathrm{EMBI}=$ channel embeddedness; $\mathrm{TPI}=$ total phosphorus; $\mathrm{TNI}=$ total nitrogen; $\mathrm{SCI}=$ specific conductance. $\mathrm{CTI}=$ combined tolerance value. Combined tolerance values for collections (WADJUS) were adjusted to a scale of 0 to 10 according to Barbour et al. (1999) and compared with U.S. Environmental Protection Agency (USEPA) tolerance values for other regions when available. Species are arranged from most sensitive to most tolerant according to the adjusted (WADJUS) tolerance value. NA = not available.

\begin{tabular}{|c|c|c|c|c|c|c|c|}
\hline Caddisfly species & EMBI & TPI & TNI & SCI & CTI & WADJUS & USEPA \\
\hline Banksiola crotchi & 1 & 1 & 5 & 5 & 12 & 0.1 & NA \\
\hline Rhyacophila grandis & 1 & 1 & 14 & 4 & 20 & 0.1 & 1 \\
\hline Pedomoecus sierra & 2 & 2 & 10 & 10 & 24 & 0.2 & 0 \\
\hline Allocosmoecus partitus & 4 & 1 & 32 & 10 & 47 & 0.5 & 0 \\
\hline Lepidostoma hoodi & 3 & 2 & 19 & 27 & 51 & 0.5 & NA \\
\hline Rhyacophila tucula & 3 & 1 & 24 & 32 & 60 & 0.6 & NA \\
\hline Ecclisocosmoecus scylla & 6 & 3 & 30 & 22 & 61 & 0.6 & 1 \\
\hline Wormaldia occidea & 2 & 6 & 20 & 45 & 73 & 0.7 & NA \\
\hline Glossosoma wenatchee & 5 & 4 & 33 & 34 & 76 & 0.8 & NA \\
\hline Rhyacophila vaefes & 4 & 3 & 48 & 22 & 77 & 0.8 & 1 \\
\hline Rhyacophila bifila & 5 & 4 & 32 & 42 & 83 & 0.8 & NA \\
\hline Agapetus taho & 5 & 3 & 42 & 43 & 93 & 0.9 & NA \\
\hline Glossosoma penitum & 7 & 5 & 40 & 43 & 95 & 1.0 & NA \\
\hline Ecclisomyia maculosa & 5 & 3 & 48 & 42 & 98 & 1.0 & NA \\
\hline Hesperophylax alaskensis & 25 & 5 & 41 & 28 & 99 & 1.0 & NA \\
\hline Himalopsyche phryganea & 9 & 6 & 40 & 44 & 99 & 1.0 & NA \\
\hline Dolophiloides pallidipes & 6 & 5 & 29 & 62 & 102 & 1.0 & NA \\
\hline Parapsyche almota & 3 & 7 & 37 & 56 & 103 & 1.0 & 3 \\
\hline Amiocentrus aspilus & 7 & 13 & 59 & 24 & 103 & 1.0 & 2 \\
\hline Rhyacophila vocala & 12 & 5 & 52 & 46 & 115 & 1.2 & NA \\
\hline Dicosmoecus atripes & 6 & 11 & 55 & 45 & 117 & 1.2 & 1 \\
\hline Chyranda centralis & 14 & 7 & 58 & 39 & 118 & 1.2 & 1 \\
\hline Neothremma didactyla & 12 & 6 & 70 & 31 & 119 & 1.2 & NA \\
\hline Neophylax occidentis & 4 & 8 & 40 & 72 & 124 & 1.2 & 3 \\
\hline Ecclisomyia conspersa & 13 & 6 & 72 & 42 & 133 & 1.3 & NA \\
\hline Polycentropus denningi & 5 & 7 & 63 & 58 & 133 & 1.3 & NA \\
\hline Rhyacophila hyalinata & 6 & 6 & 26 & 95 & 133 & 1.3 & NA \\
\hline Goeracea genota & 4 & 18 & 13 & 107 & 142 & 1.4 & 0 \\
\hline Oligophlebodes sierra & 12 & 5 & 89 & 54 & 160 & 1.6 & NA \\
\hline Parapsyche elsis & 19 & 9 & 64 & 70 & 162 & 1.6 & 1 \\
\hline Homophylax andax & 30 & 7 & 65 & 60 & 162 & 1.6 & NA \\
\hline Hydroptila rono & 3 & 3 & 111 & 46 & 163 & 1.6 & NA \\
\hline Rhyacophila narvae & 2 & 4 & 131 & 27 & 164 & 1.6 & NA \\
\hline Neophylax splendens & 4 & 22 & 26 & 137 & $\begin{array}{l}104 \\
189\end{array}$ & $\begin{array}{l}1.0 \\
2.0\end{array}$ & 3 \\
\hline Arctopsyche grandis & 33 & 15 & 85 & 65 & 198 & 2.0 & 2 \\
\hline Neophylax rickeri & 5 & 3 & 150 & 52 & 210 & 2.1 & 3 \\
\hline Mystacides alafimbriata & 33 & 2 & 158 & 24 & 217 & 2.1 & NA \\
\hline Rhyacophila angelita & 13 & 8 & 136 & 68 & 224 & 2.2 & NA \\
\hline Stactobiella delira & 38 & 8 & 112 & 71 & 229 & 2.3 & NA \\
\hline Rhyacophila brunnea & 22 & 5 & 148 & 56 & 231 & 2.3 & NA \\
\hline Hesperophylax designatus & 7 & 19 & 128 & 78 & 232 & 2.3 & NA \\
\hline Rhyacophila vao & 7 & 6 & 172 & 55 & 240 & 2.3 & NA \\
\hline Rhyacophila vaccua & 9 & 5 & 171 & 57 & 242 & 2.4 & NA \\
\hline Dolophilodes dorcus & 9 & 9 & 148 & 78 & 244 & 2.4 & $\mathrm{NA}$ \\
\hline Dicosmoecus gilvipes & 4 & 3 & 224 & 50 & 281 & 2.8 & 2 \\
\hline Dolophiloides novusamericanus & 4 & 11 & 192 & 80 & 287 & 2.9 & $\mathrm{NA}$ \\
\hline Hydatophylax hesperus & 13 & 6 & 223 & 69 & 311 & 3.1 & $\mathrm{NA}$ \\
\hline Micrasema bactro & 9 & 8 & 211 & 83 & 311 & 3.1 & 1 \\
\hline Brachycentrus americanus & 36 & 13 & 179 & 92 & 320 & 3.2 & 1 \\
\hline Hydropsyche oslari & 35 & 16 & 200 & 98 & 349 & 3.5 & 4 \\
\hline Rhyacophila vuzana & 21 & 7 & 261 & 70 & 359 & 3.5 & NA \\
\hline Wormaldia gabriella & 7 & 11 & 294 & 95 & 407 & 4.0 & NA \\
\hline Lepidostoma unicolor & 14 & 19 & 288 & 87 & 408 & 4.0 & $\mathrm{NA}$ \\
\hline Lepidostoma rayneri & 21 & 13 & 290 & 88 & 412 & 4.1 & NA \\
\hline Polycentropus variegatus & 22 & 16 & 301 & 75 & 414 & 4.1 & NA \\
\hline Hydropsyche occidentalis & 25 & 35 & 210 & 161 & 431 & 4.3 & 4 \\
\hline Ptilostomis ocellifera & 26 & 5 & 365 & 58 & 454 & 4.5 & NA \\
\hline Lepidostoma roafi & 28 & 9 & 297 & 127 & 461 & 4.6 & NA \\
\hline
\end{tabular}


TABLE 3. Continued.

\begin{tabular}{lcrrrrrc}
\hline Caddisfly species & EMBI & TPI & TNI & SCI & CTI & WADJUS & USEPA \\
\hline Lenarchus vastus & 39 & 15 & 363 & 60 & 477 & 4.8 & NA \\
Limnephilus fumosus & 20 & 4 & 390 & 67 & 481 & 4.8 & NA \\
Psychoglypha alascensis & 35 & 23 & 347 & 131 & 536 & 5.3 & NA \\
Lepidostoma rayneri & 23 & 20 & 429 & 99 & 571 & 5.6 & NA \\
Onocosmoecus unicolor & 29 & 18 & 436 & 105 & 588 & 5.6 & 2 \\
Cheumatopsyche analis & 25 & 14 & 432 & 121 & 592 & 6.0 & NA \\
Lepidostoma cascadense & 7 & 7 & 468 & 178 & 660 & 6.6 & NA \\
Hydroptila hamata & 82 & 15 & 451 & 115 & 663 & 6.7 & NA \\
Hydropsyche amblis & 10 & 10 & 572 & 131 & 723 & 7.2 & NA \\
Oecetis inconspicua & 50 & 21 & 629 & 101 & 801 & 8.0 & 8 \\
Oxyethira serrata & 99 & 104 & 475 & 212 & 890 & 8.9 & NA \\
Hydroptila arctia & 32 & 11 & 694 & 160 & 897 & 9.0 & NA \\
Agraylea multipunctata & 73 & 49 & 630 & 153 & 905 & 9.0 & 8 \\
Trianenodes tardus & 41 & 32 & 709 & 128 & 910 & 9.0 & 6 \\
Polycentropus cinereus & 118 & 15 & 680 & 100 & 913 & 9.1 & NA \\
Hydroptila xera & 146 & 95 & 510 & 346 & 1097 & 10.0 & NA \\
\hline
\end{tabular}

Cheumatopsyche analis, Hydroptila spp., Lepidostoma unicolor, Oxyethira spp., Polycentropus variegatus, and Ptilostomis ocellifera.

Arctopsyche grandis, Brachycentrus americanus, Ecclisomyia conspersa, Hydroptila arctia, Hydropsyche oslari, Onocosmoecus unicolor, Polycentropus variegatus, and Stactobiella delira were common species in each of the rivers on both west and east sides of the Cascade Range. These 8 species in clusters C and D composed at least $46 \%$ of the caddisfly assemblage in each of the 19 rivers on both sides of the Cascades.

\section{Caddis Tolerance Values}

Caddis tolerance values for nutrients (TPI, TNI), specific conductance (SCI), channel embeddedness (EMBI), and a combined Caddisfly Tolerance Index (CTI) are provided in Table 3 for 74 of the more common species in the region. The CTI values ranged from 0 to 10 , with tolerance values $\leq 2.0$ considered more sensitive to the combined measured environmental metrics and tolerance values $\geq 4.0$ considered more tolerant to the measured environmental parameters.

Species in Rhyacophilidae, Hydropsychidae, and Limnephilidae had the widest range of CTI values throughout the region (Table 3). Rhyacophilidae species, including Rhyacophila grandis, R. bifila, R. tucula, and $R$. vaefes were found to be highly sensitive (CTI $\leq 1.0$ ), whereas $R$. vedra and R. vuzana were more tolerant $(\mathrm{CTI} \geq 3.5)$. Species in Glossosomatidae, Philopotamidae, and Uenoidae commonly had the lowest CTI values $(\mathrm{CTI}<$
1.5), whereas species in Hydropsychidae, Hydroptilidae, and Leptoceridae had the highest values $(\mathrm{CTI}>3.0)$.

Caddisfly assemblages in agricultural and urban landscapes had CTI values ranging from 3.5 to 10 and were common in lowerelevation streams and lakes with fine sediments. These landscapes commonly included Arctopsyche grandis, Hydropsyche oslari, Lepidostoma cascadense, Lepidostoma unicolor, Onocosmoecus unicolor, and Polycentropus variegatus. Ninety-six percent of the caddisfly species with a CTI ranking $\geq 3.5$ were collected on the west side compared to $64 \%$ on the east side of the Cascade Range (Appendix 2, Table 3)

In contrast, caddisfly assemblages in forest landscapes had CTI values ranging from 0.2 to 1.6 and were commonly associated with small, cool mountain streams (Table 3). Some of the more common species in forest landscapes included Chyranda centralis, Ecclisocosmoecus scylla, Ecclisomyia conspersa, Glossosoma penitum, Oligophlebodes sierra, Parapsyche elsis, and R. vocala.

\section{Discussion}

Caddisfly species richness declined as channel conditions deteriorated throughout the study area. Céréghino et al. (2003) determined species richness to be a valuable tool for assessing disturbance when a limited number of environmental variables are examined. Also, Martel et al. (2007) reported that caddisfly species richness had the greatest decline in areas after clear-cutting of forests. 
Recently, Landeiro et al. (2012) tested the importance of dispersal processes versus in situ environmental factors on the composition of caddisfly species in Amazonian streams. They found that caddisflies were more dependent on environmental gradients within streams than on dispersal processes; therefore, caddisflies were good indicators of site properties and disturbance in monitoring programs. Miller et al. (2002) also found similar results for Helicopsyche mexicana and Gumaga griseola in the White Mountains of eastern Arizona.

The hierarchical multilevel dendrogram indicated that adult caddisflies were useful environmental indicators for both landscape and habitat conditions in Washington (Fig. 3). Caddisfly assemblages were separated into distinct clusters that included habitats associated with high-altitude landscapes, limited land use, agricultural and urban landscapes, and lowaltitude streams and rivers on the west side of the Cascade Range and high-altitude streams and rivers on the east side (Fig. 3).

Pauls et al. (2006) reported a high level of genetic differentiation among mountain range populations of the caddisfly species Drusus discolor, which suggested limited adult dispersal capabilities between and over mountain ranges. Therefore, it is likely that a combination of both altitude and dispersal properties may be operating.

Several investigators have employed tolerance values or rankings for caddisflies under a variety of land-use conditions, but none have been developed for the state of Washington. Many of these rankings operate at the generic level (Black et al. 2004, Couceiro et al. 2007, Silalom et al. 2006), with only a few at the species level (Barbour et al. 1999, Blinn and Ruiter 2006, Houghton et al. 2011). Smith et al. (2007) used TP and nitrate to establish nutrient tolerance values in New York for stream macroinvertebrates and they determined TP and nitrate optima values for assorted caddisfly taxa.

Our Caddisfly Tolerance Index (CTI) rankings at the species level showed close agreement with published tolerance values for caddisfly species in Idaho (Northwest) listed by the United States Environmental Protection Agency (Barbour et al. 1999). Twenty-eight of the 56 caddisfly species listed from the Northwest were collected in this study, 17 of which were within one unit, and all but 4 within 2 units of the tolerance values. Also, our CTI results were generally within 1-2 units of the nutrient tolerance values for similar caddisfly genera and species reported by Smith et al. (2007). The large number and variety of sites, the multiple physicochemical parameters (TN, TP, specific conductance, and embeddedness), and the high level of taxonomic resolution increased the sensitivity of our tolerance index. Also, repeated collections at many sites over several years enhanced the utility of the tolerance index.

Though CTI values in Table 3 provide a cumulative evaluation of 4 environmental parameters, numeric values of each determinant can also be informative. For example, Allocosmoecus paritus had a low CTI value and low values for TP, specific conductivity, and embeddedness, but a relatively high value for $\mathrm{TN}$ (Table 3). Allocosmoecus partitus was exclusively collected in small, low-elevation $(\leq 500$ $\mathrm{m})$ streams in forested areas with limited agricultural/recreational activities. This suggests that these habitats are at the initial stages of stream modification. Therefore, the disappearance of A. partitus might serve as an early indicator of disturbance in the surrounding landscape.

TPI values were relatively low throughout the caddisfly assemblages, which may suggest that TP is less of a disturbance factor than TN in Washington landscapes. However, the high TPI values for Hydroptila xera and Oxyethira serrata suggest a tolerance to TP (Table 3). These 2 species were collected in agricultural landscapes in Whatcom County, including California Creek, Fish Trap Creek, Terrell Creek, Lake Padden, Scudder Pond, Silver Lake, and Sumas River. TP levels were generally at least an order of magnitude higher in all of these systems compared to other aquatic habitats throughout the study area (Appendix 1).

Both TNI and SCI, however, had a much higher and wider range of values across the caddisfly assemblages (Table 3). Law et al. (2004) reported how human activities in urban areas can increase inputs of nitrogen. Also, elevated specific conductance values result from water running off impervious streets and parking lots that contain higher levels of inorganic dissolved solids such as chloride, sulfate, sodium, and calcium (Roy and Shuster 2009).

Black et al. (2004) ranked 45 stream sites in the Puget Sound Basin based on the level of 
urban and agricultural disturbance. Fourteen of these streams were in the Nooksack River watershed and were included in our study. Six of these sites had watersheds with $<1 \%$ disturbance, whereas 8 sites had watersheds with $22 \%$ to $86 \%$ disturbance. The average altitude for sites with high disturbance was $69 \mathrm{~m}$ (SE 25), which suggests that most of these streams were influenced by agricultural and urban activities.

In a comparison of CTI rankings to the disturbance rankings of Black et al. (2004), the average CTI value for caddisfly assemblages in sites in the Nooksack River watershed with low disturbance was 385 (SE 46) compared to 671 (SE 51) for sites with high disturbance. Therefore, caddisfly tolerance metrics can be a useful approach for monitoring changes in lotic ecosystems.

Disparities in CTI values for individual species may result from several factors. One species may have a relatively high tolerance value for 1 of the 4 measured variables, especially TN, and yield an overall high CTI value. Also, species from a nearby disturbed site may fly to a less disturbed site and influence the CTI value of the latter site. Therefore, species assemblages provide a more realistic evaluation of environmental conditions than individual species.

Abell et al. (2000) reported greater threats to aquatic ecosystems on the west side of the North Cascade Range compared to those on the east. The overall higher CTI values for caddisfly assemblages on the west side also suggest greater threats to this area.

Also, average $\mathrm{TN}$ in habitats west of the Cascades was 7 times higher than $\mathrm{TN}$ of habitats on the east side (Table 2). Crop, dairy, and livestock farming are common west of the Cascades, especially in Whatcom County, whereas dry-land farming and ranching are prominent east of the Cascades (personal observation). Farms on the west side frequently use manure as a nutrient source for crop production. If manure applications exceed the capacity of the crop to incorporate the nutrients, a surplus will remain in the soil and eventually move into streams and rivers on the watershed (Cogger et al. 1999). The higher levels of TN in streams on the west side compared to the east side suggest this may be occurring.

In addition, average specific conductance was $25 \%$ higher in streams on the west side, which may be due in part to regions of poorly drained soils in Whatcom County (Goldin 1992). There were significant negative correlations between TN and specific conductivity with species richness in the study area (Table 1).

Several other factors were important in determining caddisfly distributions. No adult caddisflies were collected in light traps at air temperatures $\leq 9{ }^{\circ} \mathrm{C}$. Blinn and Ruiter (2006) also reported no adult caddisfly captures at temperatures $<12{ }^{\circ} \mathrm{C}$ throughout Arizona, and Kimura et al. (2008) found no adults in light traps at temperatures $<10.7^{\circ} \mathrm{C}$ in the Shinano River in central Japan. Abundance, diversity of adult caddisflies, and proportion of males were also reduced at dusk temperatures $<10{ }^{\circ} \mathrm{C}$ in the northern regions of Minnesota (Houghton 2004). Furthermore, Waringer (1991) reported that dusk temperature greater than $7{ }^{\circ} \mathrm{C}$ was necessary to obtain a representative sample.

No larval or adult caddisflies were collected in California Creek (Site 2; Appendix 1). This is a 1st-order tidal stream in an agricultural region with limited hard surfaces and fluctuating specific conductance readings as high as $50 \mathrm{mS} \cdot \mathrm{cm}^{-1}$. To date, there are only a few reports of caddisfly larvae inhabiting marine and/or inland saline systems in North America (Colburn 1983, Flint and Giberson 2005), and none reported from coastal regions in Washington. Colburn (1983) reported Limnephilus assimilis from inland saltwater habitats in Death Valley, California, with salinities from 11 to $25 \mathrm{ppt}$, and Flint and Giberson (2005) reported Limnephilus ademus in salt marshes with salinities from 5 to 25 ppt in Prince Edward Island, Canada.

In addition, no larval or adult caddisflies were collected at the 2 lower sites of Nooksack River in Lynden and Slater Bridge (Sites 1 and 17; Appendix 1). These 2 sites are 4thto 5th-order river sites with limited hard surfaces for larval attachment in a heavy dairy and crop farming region.

Future studies are needed in the Columbia Unglaciated freshwater ecoregion that runs along the southern border of Washington and into Oregon and Idaho in the Blue Mountains of the Umatilla National Forest (Abell et al. 2000). This region escaped glaciation during the Pleistocene and may yield endemic invertebrates not yet described (Scudder 1996). This may be especially true for seeps and springs in the region. 


\section{ACKNOWLEDGMENTS}

We thank Dr. Oliver Flint Jr. for collections of Apatania sorex, and Ashley Rawhouser and Dr. Leo Bodensteiner for collections in the North Cascades National Park. We also thank Joan Vandersypen and Dr. Robin Mathews at the Institute for Watershed Studies at Western Washington University for nutrient analyses. Jon Vanderheyden and Don Phillips (district rangers) assisted with the acquisitions of collecting permits for the study areas. Dr. Robin Mathews provided multilevel hierarchical clustering models and Kendall's $\tau$ rank-based correlations between caddisfly species richness and abiotic factors. Luke Myers assembled the site maps, and Sandra L. Blinn assisted with collections. J. Pappani, Monitoring and Assessment Coordinator in the Idaho Department of Environmental Quality, provided a list of species from Idaho. Lastly, we thank 2 anonymous reviewers and the associate editor for their helpful comments.

\section{Literature Cited}

Abell, R.A., D.M. Olson, E. Dinerstein, P.T. Hurley, J.T. Diggs, W. Eichbaum, S. Walters, W. WettenGel, T. Allnutt, C.L. Loucks, and P. Hedao. 2000. Freshwater ecoregions of North America: a conservation assessment. Inland Press, Washington, DC. 319 pp.

[APHa] American Public Health Association. 2005. Standard methods for the examination of water and wastewater. 21st edition. American Public Heath Association, American Water Works Association, and Water Environment Federation, Washington, DC.

Anderson, N.H. 1976. The distribution and biology of the Oregon Trichoptera. Technical Bulletin 134, Agricultural Experiment Station, Oregon State University, Corvallis, OR. 152 pp.

Barbour, M.T., J. Gerritson, B.D. Snyder, and J.B. STRIBLING. 1999. Rapid bioassessment protocols for use in streams and wadeable rivers: periphyton, benthic macroinvertebrates and fish. EPA 841-B-99002, Office of Water, U.S. Environmental Protection Agency, Washington, DC.

Barbour, M.T., J.B. Stribling, and J.R. Karr. 1995. Multimetric approach for establishing biocriteria and measuring biological condition. Pages 63-77 in W.S. Davis and T.P. Simon, editors, Biological assessment and criteria: tools for water resource planning and decision making. Lewis Publishers, Boca Raton, FL.

Ben-Hur, A., And I. GuYon. 2003. Detecting stable clusters using principal components analysis. Pages 159-182 in M.J. Brownstein and A. Kohodursdy, editors, Methods in molecular biology. Humana Press, New York, NY.

BetTs, B.J., and R.W. Wisseman. 1995. Geographic range and habitat characteristics of the caddisfly Cryptochia neosa. Northwest Science 69:46-51.
Black, R.W., M.D. Munn, and R.W. Plotnikoff. 2004. Using macroinvertebrates to identify biota-land cover optima at multiple scales in the Pacific Northwest USA. Journal of the North American Benthological Society 23:340-362.

BLINN, D.W. 1993. Diatom community structure along physicochemical gradients in saline lakes. Ecology 74:1246-1263.

Blinn, D.W., AND P.C.E. Bailey. 2001. Land-use influence on stream water quality and diatom communities in Victoria, Australia: a response to secondary salinization. Hydrobiologia 466:231-244.

Blinn, D.W., AND D.E. Ruiter. 2006. Tolerance values of stream caddisflies (Trichoptera) in the lower Colorado River Basin, USA. Southwestern Naturalist 51:326-337.

Cannings, R.A. 2007. Checklist of Trichoptera (Caddisflies) of British Columbia. In: B. Klinkenberg, editor. 2011. E-Fauna BC: electronic atlas of the fauna of British Columbia. Lab for Advanced Spatial Analysis, Department of Geography, University of British Columbia, Vancouver, British Columbia, Canada. Available from: http://www.efauna.bc.ca

Céréghino, R., Y.-S. Park, A. Compin, And S. LeK. 2003. Predicting the species richness of aquatic insects in streams using a limited number of environmental variables. Journal of the North American Benthological Society 22:442-456.

Cogger, C.G., T.N. Cramer, A.I. Bary, and D.C. GruseMEYER. 1999. Whole farm nutrient flow and manure management. Presented at Northwest Dairy Short Course, Blaine, WA.

Colburn, E.A. 1983. Effect of elevated temperature on osmotic and ionic regulation in a salt-tolerant caddisfly from Death Valley, California. Journal of Insect Physiology 29:263-369.

Couceiro, S.R.M., N. Hamada, L. Sergio, L.B. Luz, B.R. ForsberG, AND T.P. Pimentel. 2007. Deforestation and sewage effects on aquatic macroinvertebrates in urban streams in Manaus, Amazonas, Brazil. Hydrobiologia 575:271-284.

Crawley, M.J. 2007. The R Book. Wiley Online Library. Available from: http://dx.doi.org/10.1002/978047051 5075

Cuffney, T.F., R. Kashuba, S.S. Qian, I. Alameddine, Y. Cha, B. Lee, J.F. Coles, and G. McMahon. 2011. Multilevel regression models describing regional patterns of invertebrate and algal response to urbanization across the USA. Journal of the North American Benthological Society 30:797-819.

DaVIS, J.J. 1948. The caddis flies of the state of Washington. Doctoral dissertation, Washington State University, Pullman, WA. 291 pp.

ENGER, E., AND B. Smith. 2009. Environmental science: a study of interrelationships. McGraw-Hill, New York, NY.

FLint, O.S., JR., AND D.J. Giberson. 2005. Salt marsh caddisflies: discovery of the larva and larval habitat of Limnephilus ademus in salt marshes in Prince Edward Island, Canada. Pages 121-130 in Proceedings of the 11th International Symposium on Trichoptera: Sakai, Osaka and Kutsugi, Siga, Japan, 12-19 June 2003.

GoLdin, A. 1992. Soil survey of Whatcom County area, Washington. United States Department of Agriculture, Soil Conservation Service, Washington, DC. 316 pp. Available from: http://purl.fdlp.gov/GPO/L PS106157 
Hawkins, C.P., and R.N. Norris. 2000. Performance of different landscape classifications for aquatic bioassessments: introduction to the series. Journal of the North American Benthological Society 19: 367-369.

Houghton, D.C. 2004. Biodiversity of Minnesota caddisfly (Insecta: Trichoptera): delineation and characterization of regions. Environmental Monitoring and Assessment 95:153-181.

2006. The ability of common water quality metrics to predict habitat disturbance when biomonitoring with adult caddisflies (Insecta: Trichoptera). Journal of Freshwater Ecology 21:705-716.

2011. Biological changes along the continuum of an agricultural stream: influence of a small terrestrial preserve and use of adult caddisflies in biomonitoring. Journal of Freshwater Ecology 26:381-397.

JoNgman, R.H.G., C.J.F. TER BRAAK, AND O.F.R. VAN TONGEREN, EDITORS. 1995. Data analysis in community and landscape ecology. Cambridge University Press, Cambridge, United Kingdom.

Kimura, G., E. Inoue, and K. Hirabayashi. 2008. Seasonal abundance of adult caddisfly (Trichoptera) in the middle reaches of the Shinano River in central Japan. Pages 259-266 in Proceedings of the 6th International Conference on Urban Pests.

Landeiro, V.L., L.M. Bini, A.S. Melo, A.M. Pes, and W.E. Magnusson. 2012. The roles of dispersal and environmental conditions controlling caddisfly (Trichoptera) assemblages. Freshwater Biology 57: 1554-1564.

LaW, N.L., L.E. Band, And J.M. Grove. 2004. Nitrogen input from residential lawn care practices in suburban watersheds in Baltimore County, MD. Journal of Environmental Planning and Management 47: $737-755$.

LaWs, E.A. 2000. Aquatic pollution: an introductory text. 3rd edition. John Wiley \& Sons, New York, NY.

MacDonald, L.H., A.W. Smart, and R.C. Wissmar. 1991. Monitoring guidelines to evaluate effects of forestry activities on streams in the Pacific Northwest and Alaska. EPA 910/9-91-001, U.S. Environmental Protection Agency, Seattle, WA. 166 pp.

Martel, N., M.A. Rodríguez, and P. Bérubé. 2007. Multi-scale analysis of responses of stream macrobenthos to forestry activities and environmental context. Freshwater Biology 52:85-97.

Miller, M.P., D.W. Blinn, AND P. Keim. 2002. Correlations between observed dispersal capabilities and patterns of genetic differentiation in populations of four aquatic insects from the Arizona White Mountains, U.S.A. Freshwater Biology 47:1660-1673.

Monse, J.C. 2009. Trichoptera species of America north of Mexico [online].

Neweld, R.L., And W. Minshall. 1977. An annotated list of the aquatic insects of southeastern Idaho, Part II: Trichoptera. Great Basin Naturalist 37:253-257.

Pauls, S.U., H.T. Lumbsch, and P. Haase. 2006. Phylogeography of the montane caddisfly Drusus discolor: evidence for multiple refugia and periglacial survival. Molecular Ecology 15:2153-2169.

Paulsen, S.G., A. Mayio, D.V. Peck, J.L. Stoddard, E. Targuinio, S.M. Holdoworth, J. Van Sickle, L.L. Yuan, C.P. Hawkins, A.T. Herlihy, ET aL. 2008. Conditions of stream ecosystems in the US: an overview of the first national assessment. Journal of the North American Benthological Society 27:812-821.
Platts, W.S., W.F. Megahan, and G.W. Minshall. 1983. Methods for evaluating stream, riparian, and biotic conditions. General Technical Report INT-138, USDA Forest Service, Ogden, UT.

Pojar, J., and A. MacKinnon. 1994. Plants of the Pacific Northwest Coast: Washington, Oregon, British Columbia, and Alaska. Lone Pine Publishing, Auburn, WA. 528 pp.

R Development Core Team. 2011. R: a language and environment for statistical computing. R Foundation for Statistical Computing, Vienna, Austria; [cited March 2013]. ISBN 3-900051-07-0. Available from: http://www.R-project.org/.

Ricketts, T.H., E. Dinerstein, D.M. Olson, C.L. Loucks, W. Eichbaum, D. Dellasalla, K. Kavanagh, P. Hedao, P.T. Hurley, K.M. Carney, et al. 1999. Terrestrial ecoregions of North America: a conservation assessment. Island Press, Washington, DC. $485 \mathrm{pp}$.

Roy, A.H., AND W.D. Shuster. 2009. Assessing impervious surface connectivity and applications for watershed management. Journal of the American Water Resources Association 45:198-209.

Ruiter, D.E., B.C. KondratiefF, R.A. Lechleitner, And R.E. ZuELLIG. 2005. An annotated list of the caddisflies (Trichoptera) of Mount Rainier National Park, Washington, USA. Transactions of the American Entomological Society 131:159-187.

ScudDER, G.G.E. 1996. Terrestrial and freshwater invertebrates of British Columbia: priorities for inventory and descriptive research. British Columbia Working Paper 09/1996. Research Bureau, British Columbia Ministry of the Environment. Lands and Parks. Victoria, British Columbia, Canada.

Silalom, S., J.L. Carter, and P. Chantaramongkol. 2006. Development of Trichopteran tolerance values for assessing water quality in the upper sub-watersheds of Ping River, Thailand. Proceedings of the 12th International Symposium on Trichoptera 17: 285-291.

Smith, A.J., R.W. Bode, AND G.S. KLEPPEL. 2007. A nutrient biotic index (NBI) for use with benthic macroinvertebrate communities. Ecological Indicators 7: 371-386.

Vannote, R.L., G.W. Minshall, K.W. Cummins, J.R. SEDELl, AND C.E. Cushing. 1980. The river continuum concept. Canadian Journal of Fisheries and Aquatic Sciences 37:130-137.

Waringer, J.A. 1991. Phenology and the influence of meteorological parameters on the catching success of light-trapping for Trichoptera. Freshwater Biology 25:307-319.

WhitTier, T.R., And J. VAn SickLe. 2010. Macroinvertebrate tolerance values and an assemblage tolerance index (ATI) for western USA streams and rivers. Journal of the North American Benthological Society 29:852-866.

Zack, R.S., D.E. Ruiter, D.L. Strenge, and P.J. LanDOLT. 2006. Adult caddisfly (Trichoptera) phenology at the Hanford Reach National Monument, Washington State. Proceedings of the Entomological Society of Washington 108:131-138.

Received 26 July 2012 Accepted 29 May 2013 


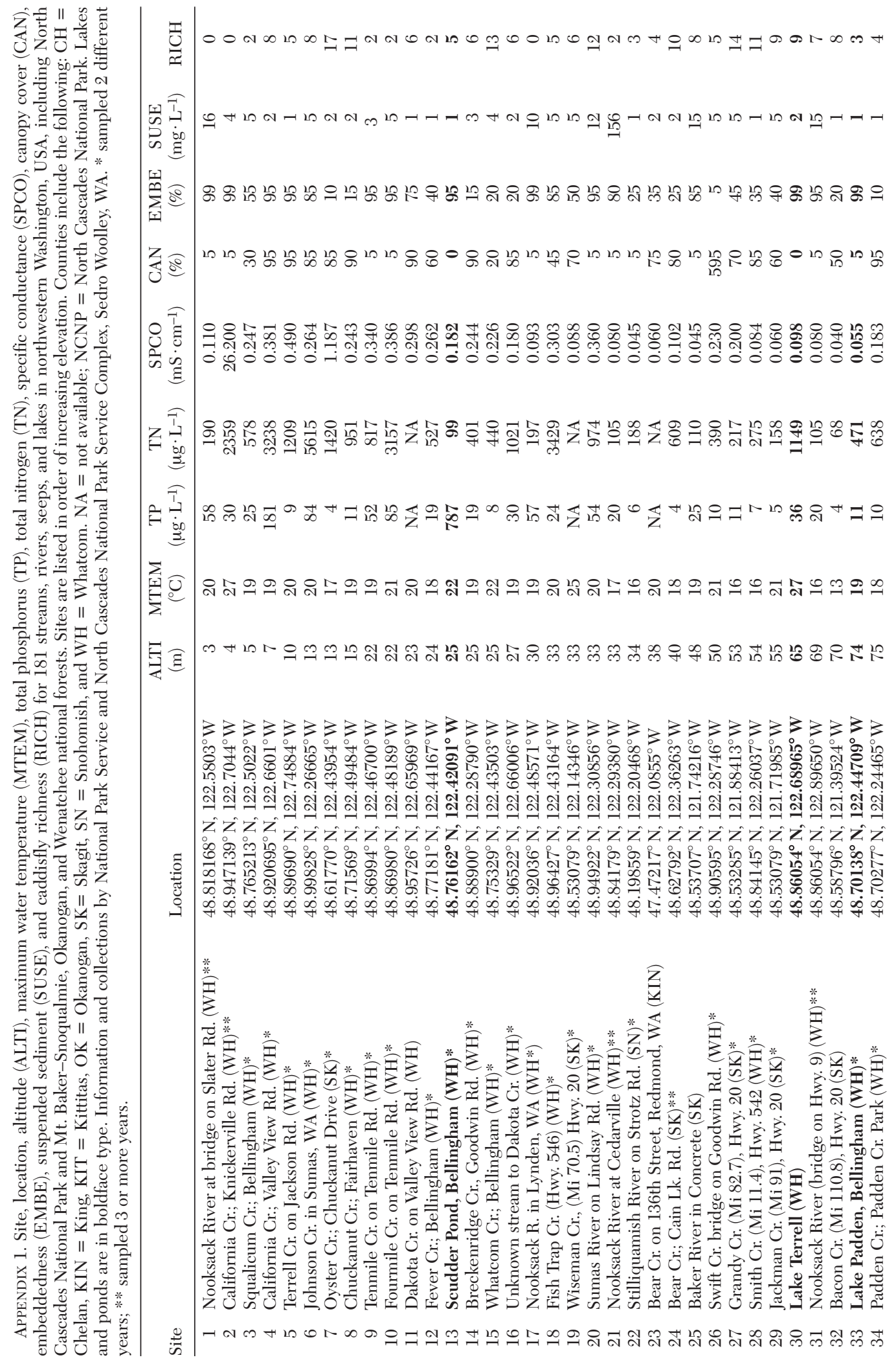




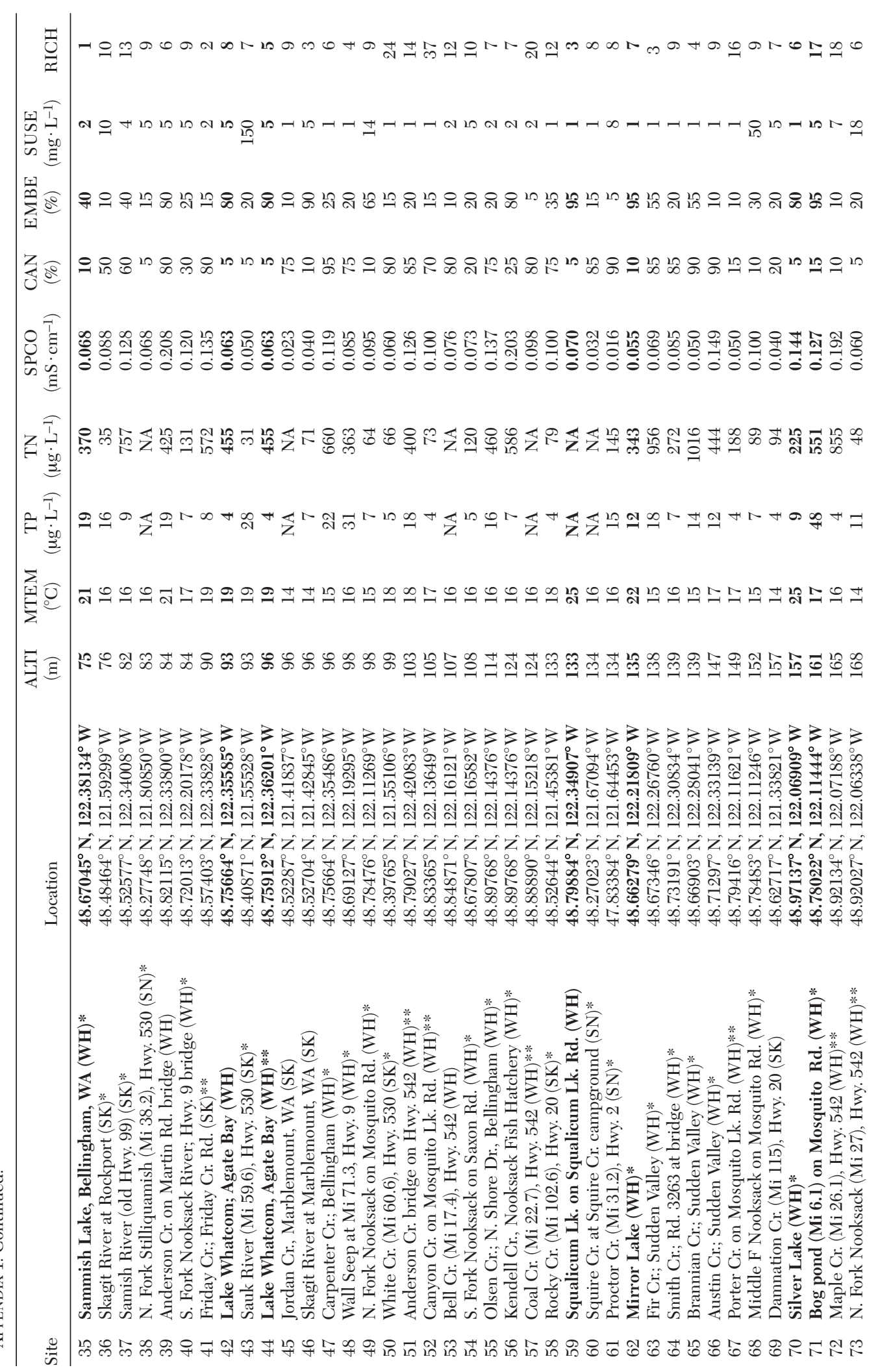




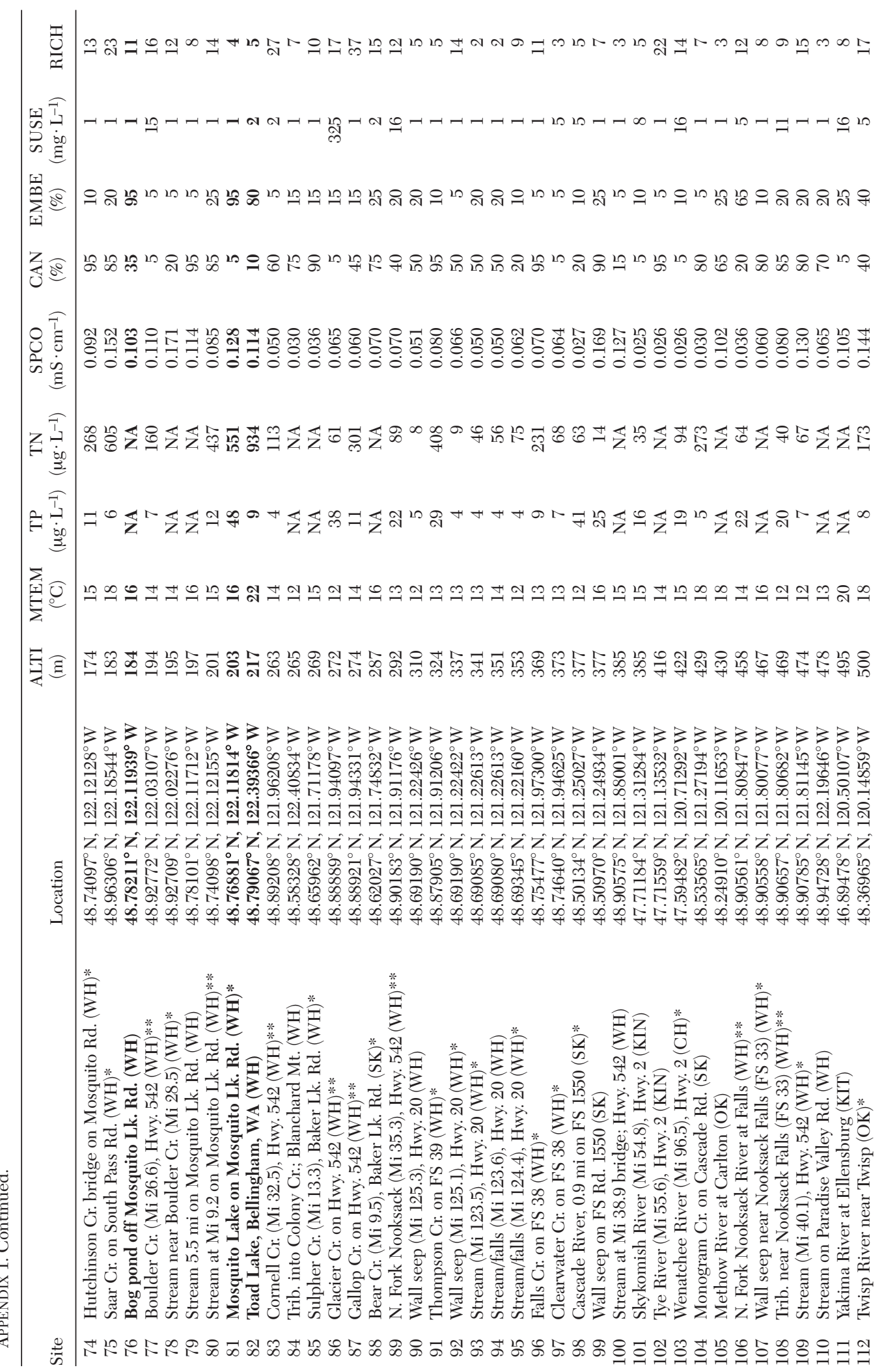




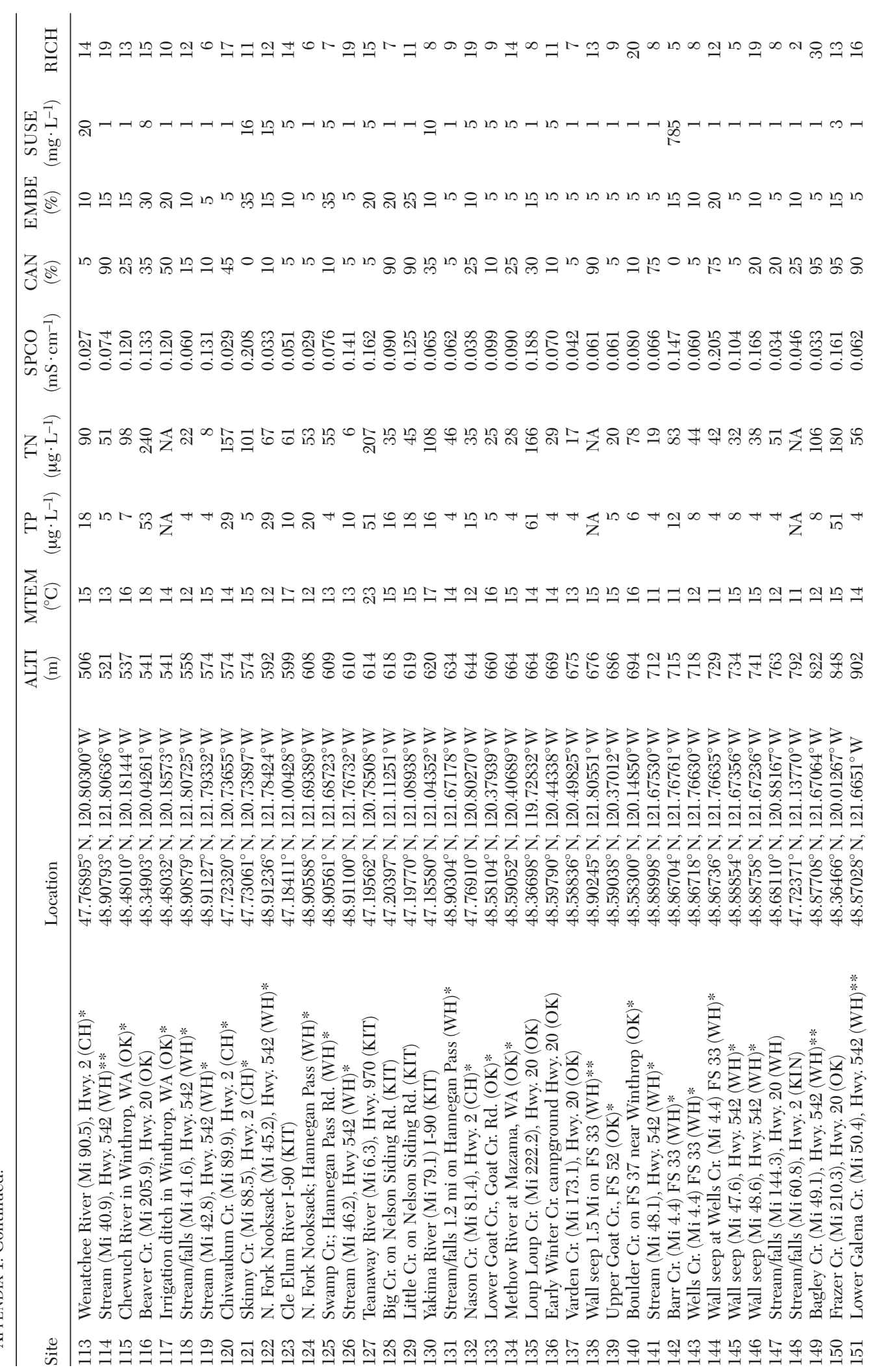




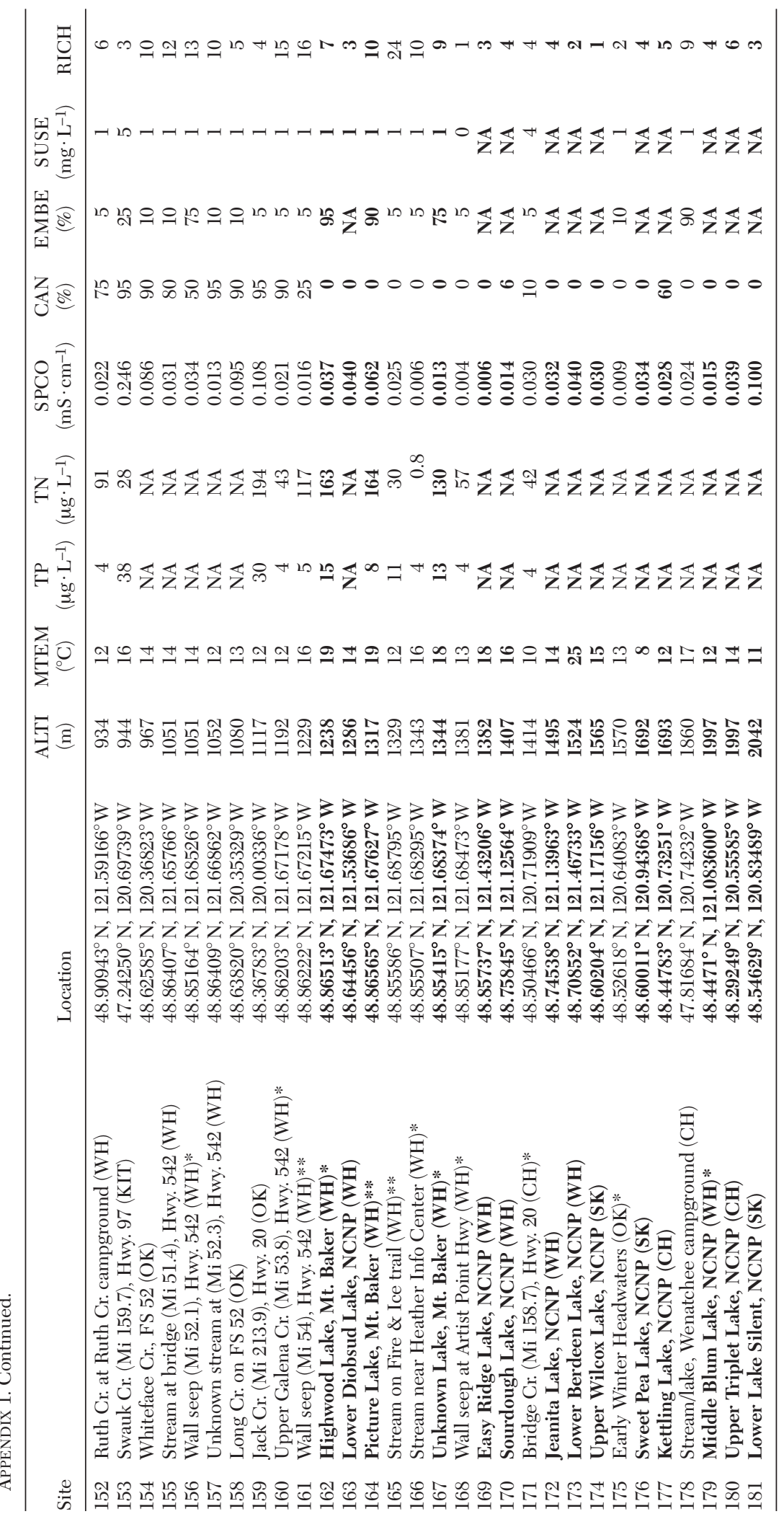




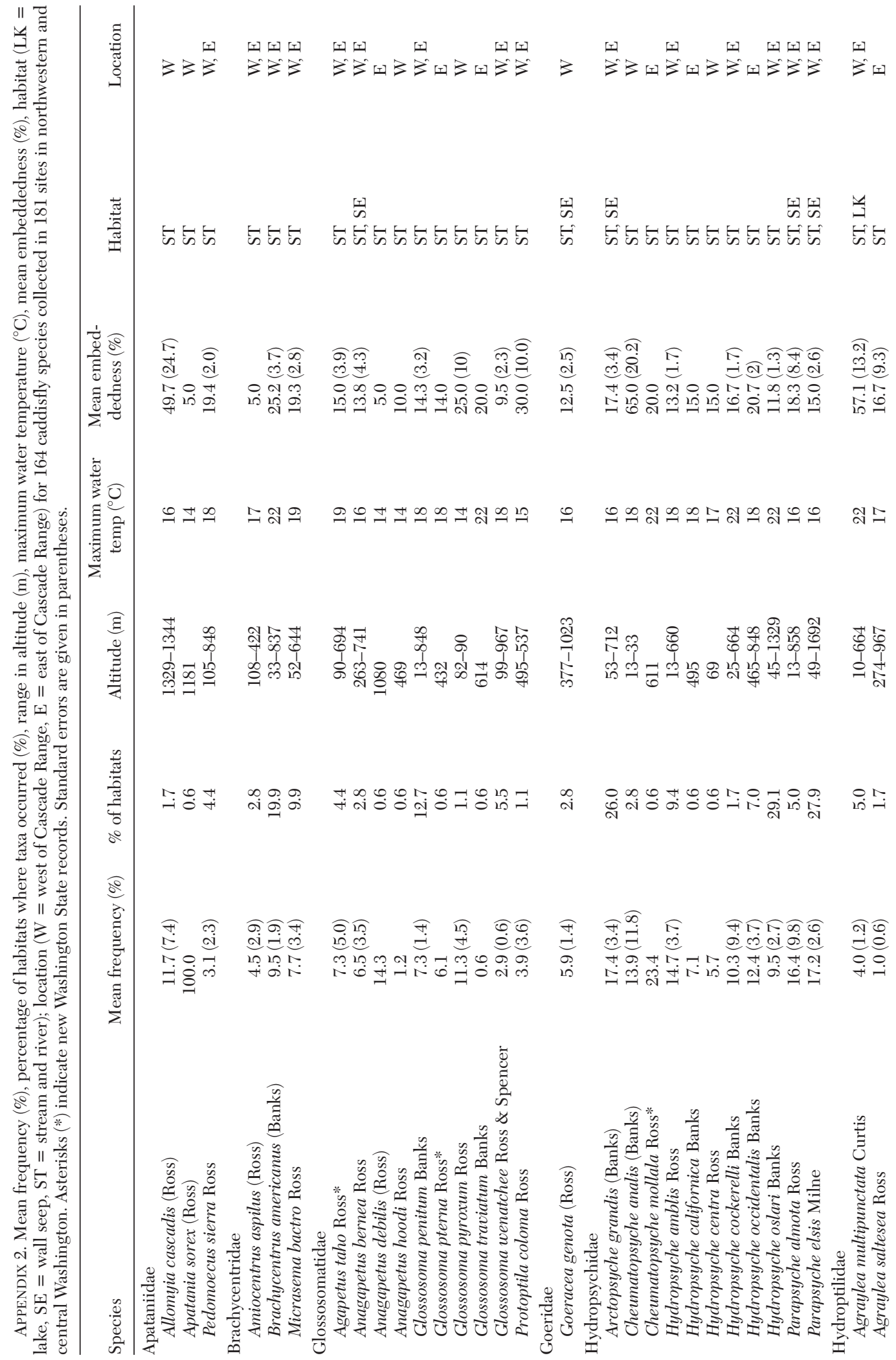




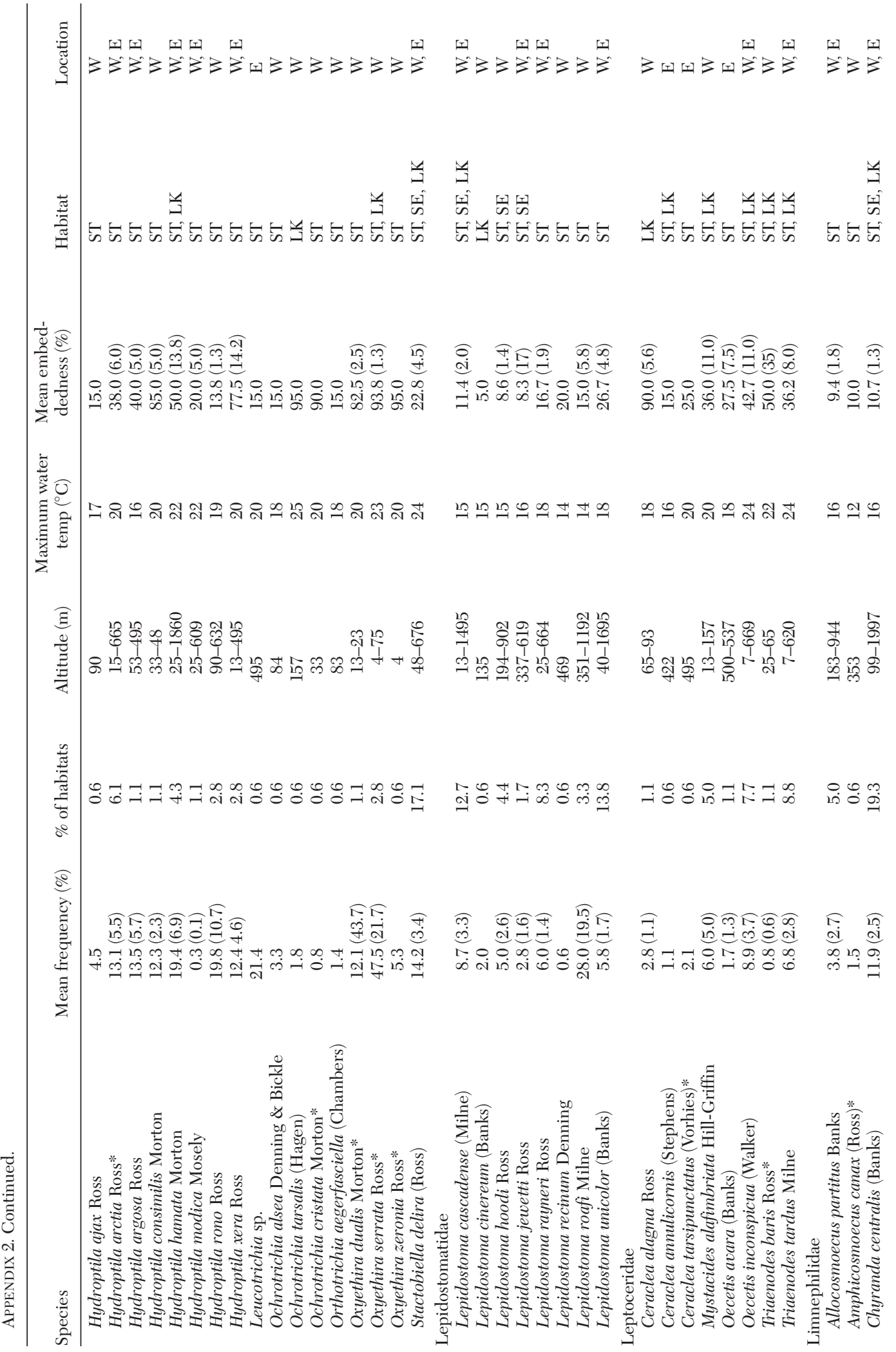




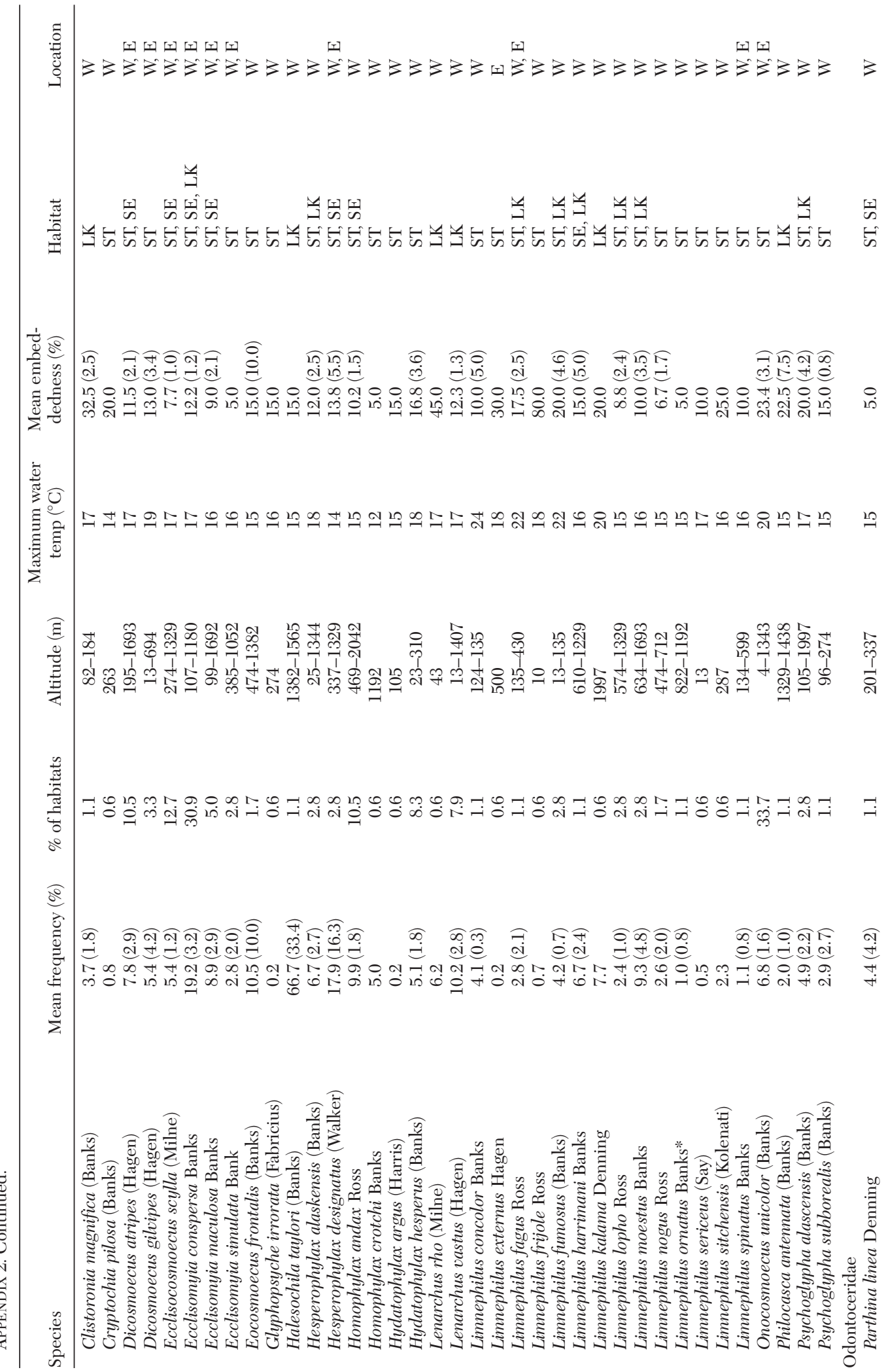




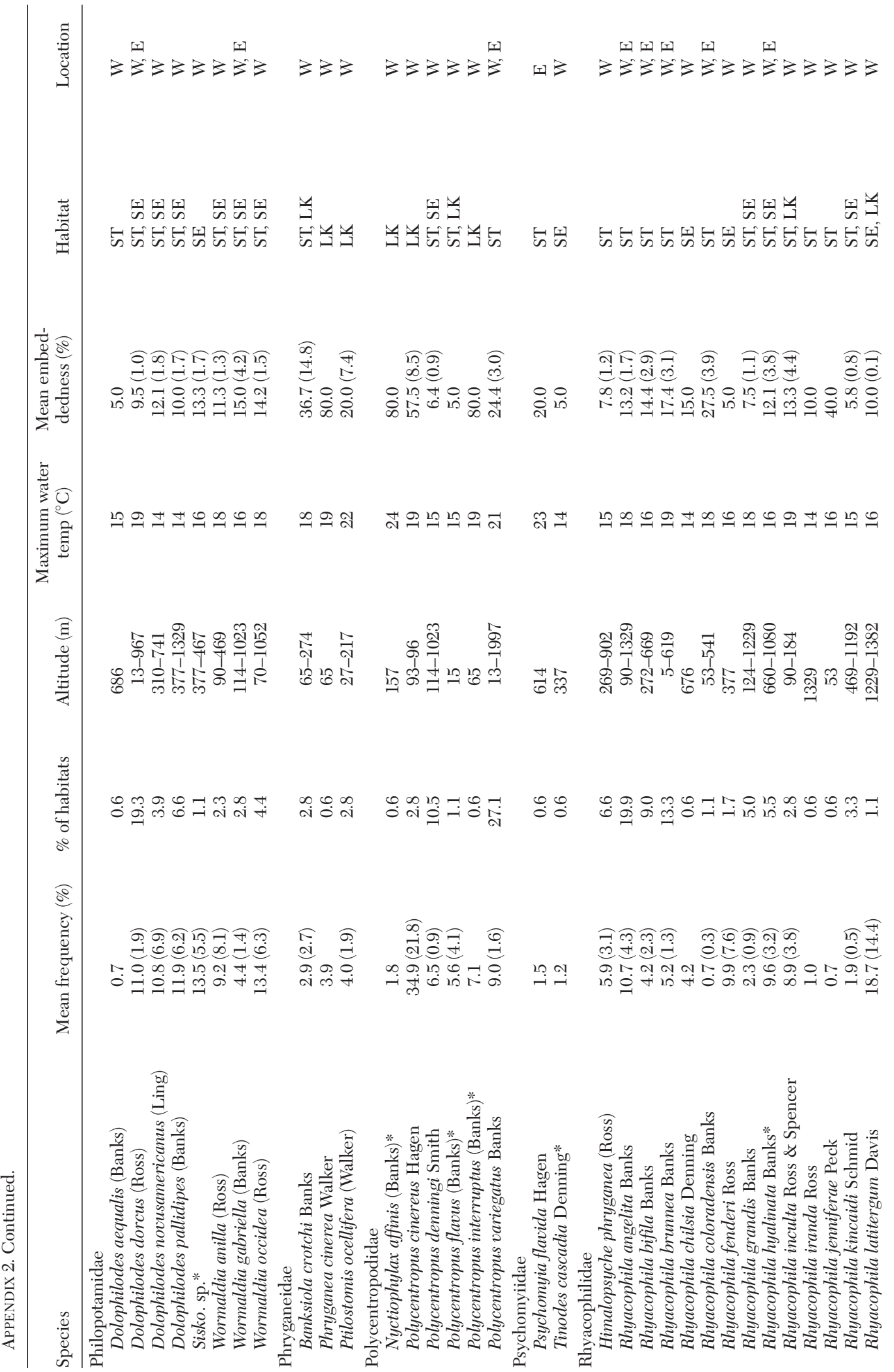




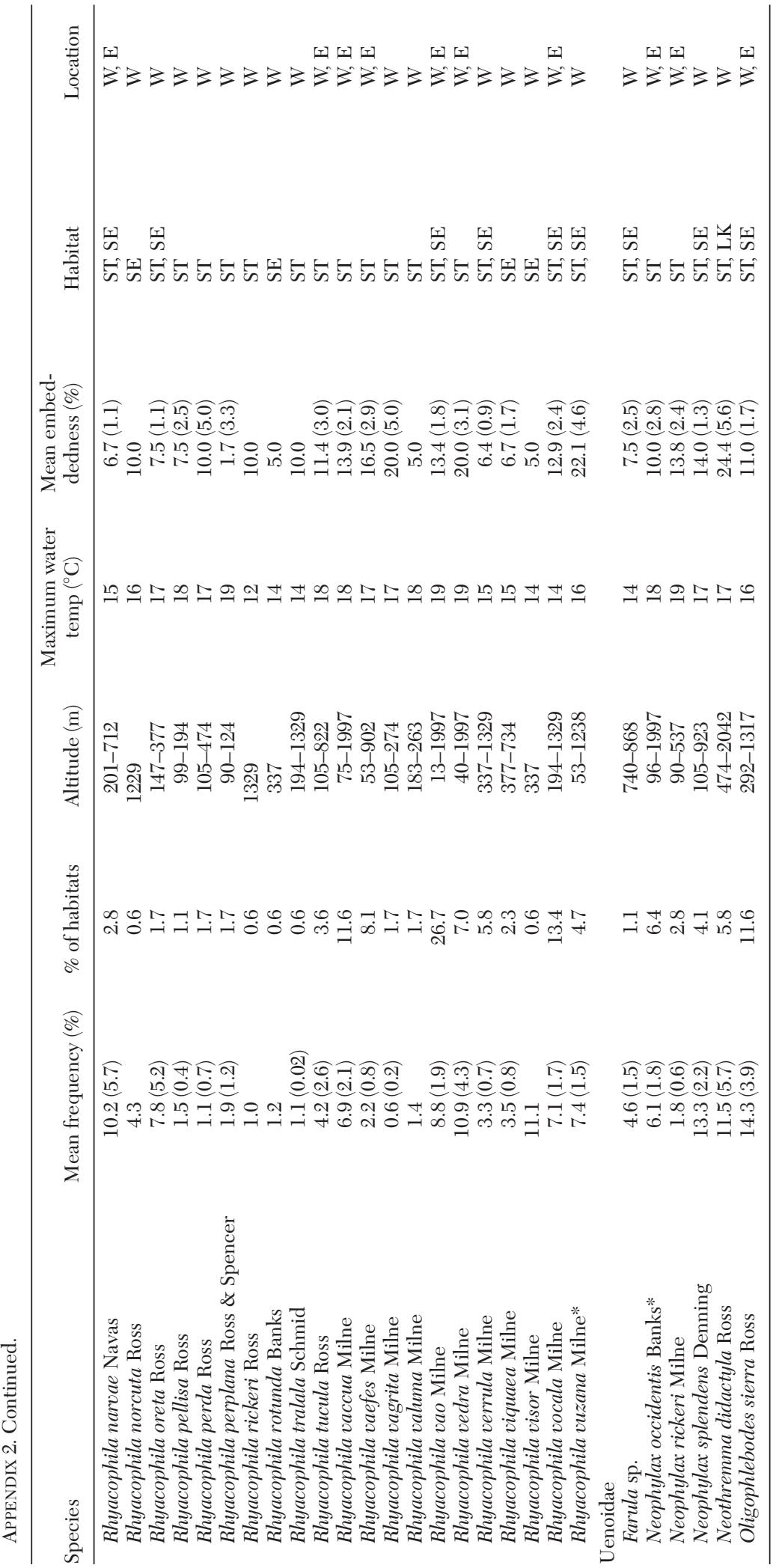

